
\title{
$\begin{array}{ll}\text { Research Square } & \begin{array}{l}\text { Preprints are preliminary reports that have not undergone peer review. } \\ \text { They should not be considered conclusive, used to inform clinical practice, } \\ \text { or referenced by the media as validated information. }\end{array}\end{array}$
}

\section{Monitoring Metallothionein-Like Protein Concentrations And Cholinesterase Activity In Tropical Cup Oysters As Biomarkers of Exposure To Metals And Pesticides In The Southern Caribbean, Colombia}

Angela M. Moncaleano-Niño

Universidad de Bogota Jorge Tadeo Lozano

Maria Camila Gómez-Cubillos

Universidad de Bogota Jorge Tadeo Lozano

Andrea Luna-Acosta

Universidad de Bogota Jorge Tadeo Lozano

Luisa Villamil

Universidad de Bogota Jorge Tadeo Lozano

Samuel Casseres-Ruiz

Universidad de Bogota Jorge Tadeo Lozano

Michael J. Ahrens ( $\nabla$ michael.ahrens@utadeo.edu.co)

Universidad de Bogota Jorge Tadeo Lozano https://orcid.org/0000-0003-3556-006X

\section{Research Article}

Keywords: Caribbean, Biomarker, cup oysters, metals, pesticides, cholinesterase, metallothionein

Posted Date: July 19th, 2021

DOI: https://doi.org/10.21203/rs.3.rs-602869/v1

License: (c) (i) This work is licensed under a Creative Commons Attribution 4.0 International License. Read Full License

Version of Record: A version of this preprint was published at Environmental Science and Pollution Research on November 27th, 2021. See the published version at https://doi.org/10.1007/s11356-021-17644-7. 


\section{Abstract}

Metallothionein-like protein concentrations (MT) and three functionally defined fractions of cholinesterase activity (ChE: total, eserinesensitive, eserine-resistant) were quantified in gill and digestive gland homogenates of tropical cup oysters from 5 nearshore locations in the Colombian Caribbean and correlated with sediment and tissue metal (9 metals) and pesticide (22 organophosphates, OPs, and 20 organochlorines- OCPs), as well as water physical-chemical parameters (salinity, $\mathrm{pH}$, temperature and dissolved oxygen). Tissue and sediment pesticide concentrations were below detection limits in all samples, whereas sediment and tissue metal concentrations exceeded environmental thresholds at several locations. Tissue MT and ChE biomarkers varied by a factor of 5-6 between locations and correlated with tissue and sediment concentrations. However, statistically significant covariance between biomarkers and water chemistry parameters was also observed, indicating that both, metal concentrations and physical-chemical variables, are likely to be responsible for generating the observed spatial-temporal variations in biomarker patterns.

\section{Introduction}

Tropical near shore ecosystems throughout the Caribbean have experienced significant modifications in recent decades, as consequence of human settlement and industrial and agricultural expansion. In addition to global climate change, coastal ecosystems are threatened at the regional scale by habitat destruction, fragmentation and resource over-extraction, as well as by a plethora of biological, chemical, and physical contaminants derived from household, industrial, roadside, and agricultural runoff (Spaliding and Kramer, 2004). Notwithstanding these ever-increasing human influences, efforts to monitor their environmental impact have generally lagged developments, with much of previous monitoring activity having focused on determining concentrations of chemical contaminants in different environmental matrices (e.g., water, sediment, tissues, e.g., Fernandez-Maestre et al. 2018). While chemical contamination monitoring is valuable for benchmarking the status and trends of coastal pollution, it is not sufficient by itself for gauging the severity of contamination, nor the likelihood of occurrence of adverse biological effects, and even less, the possible implications that these might entail for human populations that rely on ecosystem goods and services directly or indirectly (Lewis et al., 1995; Gold-Bouchot and Zapata-Pérez, 2004, Olivero-Verbel et al. 2008, Carranza-Lopez et al. 2020). Consequently, recent environmental monitoring efforts have focused on combining, or integrating, diverse indicators of exposure to chemical contamination with measures of biological effects, with the objective to detect adverse effects of contamination in organisms or communities, as well as to identify the likely causal agents (Tejeda-Benitez et al. 2016). The employed methods span the gamut from analyses of specific metabolites to molecular, biochemical and histological techniques to detect exposure or effect at the cellular level, to biological population and community-scale health assessments, including reproduction, growth and species composition (Bernal et al., 2010; Dondero et al., 2010; Aceto et al., 2011; Cravo et al., 2012; Luo et al. 2014; De Marchi et al., 2017).

In the Colombian Caribbean, environmental quality and pollution monitoring have been infrequent in the past (Alonso et al., 2000; OliveroVerbel et al., 2008; Franco and León-Luna 2010; Cordy et al., 2011) and essentially limited to determining water and, more recently, sediment concentrations of primary pollutants, such as PAHs, second-generation pesticides (organochlorines and organophosphates) and metals (Vivas-Aguas et al., 2012; 2015; Garcés- Ordoñez et al., 2016; INVEMAR, 2017). Studies of biological responses in organisms have been even fewer, and have focused primarily on bivalves (Rasmussen et al., 1983; Gold-Bouchot and Zapata-Perez, 2004; Bebianno et al., 2009; ElShenawy et al., 2009; Hédouin et al., 2011; Al- Subiai et al., 2011; Benali et al., 2017). The dearth of baseline information on the presence and levels of these pollutants in the southern Caribbean or their potential effects upon the different biological hierarchies (gene, protein, tissue, individual or population) is worrisome and impedes reliable estimates of previous, current, and future status and trends of contamination in this rapidly developing region. In light of this situation, in 2012, a pilot-scale biological exposure \& effects monitoring program (named "Proyecto Caribiopol"), was initiated as a collaboration between three universities, using bivalves as indicator organisms, akin to the landmark NOAA "Mussel Watch" (Kimbrough et al. 2008), for the purpose of comparing contamination levels in tissues between locations, but expanded to include a suite of biomarkers of exposure and effects as well (Aguirre-Rubi et al 2017, 2018).

Among environmental contaminants, two classes are ubiquitous in tropical regions: metals, derived from municipal runoff or mining/industrial activities (Olivero-Verbel et al., 2008), and pesticides, from agriculture (Menzies et al. 2013, Carvalho, 2017). Neuroactive pesticides, such as organophosphates (OPs), carbamates and neonicotinoids (NNs), are known for their neurotoxicity at the synapses, where they can inhibit the enzyme function of cholinesterases (ChE) such as acetylcholinesterase (AChE), as is the case for the OPs and carbamates, or by irreversibly blocking the nicotinic acetylcholine receptor, as is the case for NNs (Bocquene et al., 1997; Barata et al., 2004; Hernández-Moreno et al., 2010). The second common class of pollutants in the Caribbean are metals such as mercury, cadmium and lead, often associated with urban storm water industrial discharges, such as the production of chlor-alkali and fertilizers, whose presence at sufficiently high concentrations has been linked to neurological, metabolic, immunological and carcinogenic disorders in both humans and other marine and aquatic organisms (Prato et al., 2006; Ramakritinan et al., 2012; Thevenod and Lee 2013, Olivero-Verbel et al. 2008, Carranza-Lopez et al. 2020). 
As indicators of exposure to pesticides and metals, biomarker-based techniques have become common in environmental pollution studies worldwide (Bebianno and Barreira 2009; Lüchmann et al., 2011; Choi et al., 2011; Cravo et al., 2012; Ramdine et al., 2012; Serafim et al., 2012) and represent a valuable component in an integrated environmental assessment of chemical contamination effects. At the biochemical level, the measurement of the enzymatic activity of selected key enzymes has become a widely accepted technique for the evaluation of the effects of pesticides on ecosystem health. Among these, acetylcholinesterase (AChE) activity has been used as a marker of exposure to OP pesticides and carbamates, due to its inhibition of cholinesterase enzymes in the synapses of the nervous system (Monserrat et al., 2002; Monserrat et al., 2007; Bernal- Hernández et al., 2010). On the other hand, metallothionein-like proteins (MT) have been widely used as biomarkers of exposure to metals, (Montaudouin et al., 2010 and David et al., 2012), thanks to their inducibility by certain divalent nonessential metals (such as Cd, $\mathrm{Hg}$ and Pb), in contrast to essential metals such as Zn and Cu (Amiard et al., 2006). The aim of this study was to compare the variability of MT concentrations and ChEs activity in cup oysters as indicator organisms along a presumed contamination gradient of metals and pesticides along the Colombian Caribbean, to assess their merit as a monitoring technique to evaluate the environmental health of coastal ecosystems in the Colombian Caribbean.

\section{Material And Methods \\ 2.1. Sample Collection}

Field sampling was carried out on October 2012, March 2013 and October 2013 at 5 locations along the Colombian Caribbean coastline:

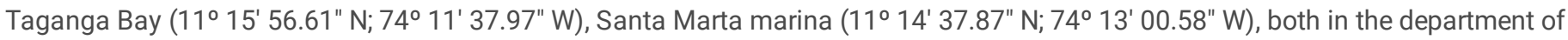
Magdalena, Barbacoas Bay (Barú Peninsula- Mohan mangrove swamp, $10^{\circ} 12^{\prime} 15.79^{\prime \prime} \mathrm{N} ; 7^{\circ} 36^{\prime} 01.11^{\prime \prime} \mathrm{W}$ ), and in two locations in Cartagena Bay, one in the Maparadita island- Ctg-1 (10²2' 21.52" N; 75³0' 46.45"W) and another in Brujas island- Ctg-2 (10 $19^{\prime} 59.07$ N; $\left.75^{\circ} 30^{\prime} 47.24^{\prime \prime} \mathrm{W}\right)$, with the three latter stations all being characterized by extensive mangrove habitat and located in the department of Bolivar (Fig. 10, also see Aguirre-Rubi et al. 2018 a,b).

At each station and on each sampling occasion, 15 live cup oysters (principally Crassostrea rhizophorae, with some individuals of the recently established and morphologically similar Saccostrea sp. interspersed in Taganga Bay and Santa Marta in 2013) were collected intertidally from docks and/or red mangrove roots (Rhizophora mangle). Oysters were transferred live to the laboratory in chilly bins, where tissues (digestive gland and gills) were dissected within a few hours of collection and frozen in $2 \mathrm{~mL}$ polypropylene tubes at $-80^{\circ} \mathrm{C}$, according to tissue type, until further processing. For biomarker analyses, digestive gland and gill tissue samples were thawed sequentially in three pools of 5 individuals and homogenized at a proportion of $0.5 \mathrm{~g}$ wet tissue per $2 \mathrm{~mL}$ phosphate buffer ( $50 \mathrm{mM}$ ) using a blender (Ultra-Turrax T8, IKA Labortechnik, Germany). Tissue homogenates were then aliquoted in sub-volumes of $200 \mu \mathrm{L}$ and re-frozen at $-80^{\circ} \mathrm{C}$ until final analysis.

Oyster collection was accompanied by the measurement of four surface water physical-chemical parameters: salinity (psu), pH, temperature $\left({ }^{\circ} \mathrm{C}\right)$ and dissolved oxygen (mg/L), using a multiparameter probe (Hach HQ40d).

\subsection{Metal and pesticide analyses in sediments and bivalve tissue}

To relate tissue biomarker levels to xenobiotic contaminant exposure, samples of sediments and bivalve tissue were analyzed. For this, $200 \mathrm{~g}$ of surface sediment (< $10 \mathrm{~cm}$ sediment depth) were collected at each station, using a cylindrical corer to maintain sample integrity and frozen at $-20^{\circ} \mathrm{C}$ in sealed polyethylene bags until processing. Sediments were dried whole at $60^{\circ} \mathrm{C}$ until constant weight, digested with a mixture of nitric/hydrochloric acid, followed by ICP-MS analysis for metals (As, Cd, Cr, Cu, Hg, Pb, Ni, Sn and Zn), carried out at a commercial laboratory (Hills Laboratory, Hamilton, New Zealand). Pesticides in sediments were analyzed at Invemar Institute, Santa Marta, Colombia: dry sediments were Soxhlet-extracted using dichloromethane, fractionated on a hexane florisil column, and analyzed for 22 organophosphates (OPs) and 20 organochlorine pesticides (OCPS) using GCMS in SIM mode (UNEP, 2008). For tissue contaminant analysis, also reported by Aguirre-Rubi et al. (2017), a composite of 30 individuals per sampling station was collected and frozen at $-20^{\circ} \mathrm{C}$. For tissue metals, $100 \mathrm{mg}$ of freeze-dried tissue homogenate was digested in a microwave oven (Multi-wave 3000, Anton Paar, Austria). The extract was filtered and subsequently analyzed for metals using an ICP-MS (NexION 300, Perkin Elmer, USA) at the Research Centre for Experimental Marine Biology and Biotechnology, University of Basque Country, Plentzia, Spain (PiE-UPV/EHU), as described in Aguirre-Rubi et al. (2017). Results for metals in sediments and tissues were obtained only for October 2012 and March 2013 (not for Oct 2013). Furthermore, no sediment metal data are available for Ctg-1 (October 2012), due to loss of sample during transport. All metal concentrations (sediment and tissue) are reported on a dry weight basis $(\mu \mathrm{g} / \mathrm{g} \mathrm{dw})$.

\subsection{Biomarker Analysis}

Metallothionein-like proteins (MT) were analyzed according to Viarengo et al. (1997), with modifications as described by Moncaleano et al. (2017), in digestive gland and gills, homogenized in phosphate buffer (0.1 M, pH 8.0) at a ratio 1:3 (w:w) and then adjusted with a sucrose- 
Tris buffer to a final concentration of $0.5 \mathrm{M}$ sucrose and $20 \mathrm{mM}$ Tris- $\mathrm{HCl}(\mathrm{pH}$ 8.6). Final tissue MT concentrations are presented as $\mu \mathrm{g} M T / \mathrm{mg}$ total protein. Cholinesterase activity (ChE) was measured according to Moncaleano et al. (2018), quantifying three fractions of cholinesterase activity: total cholinesterase (T-ChE), eserine resistant cholinesterase (Er-ChE) and eserine sensitive cholinesterase activity (Es-ChE). Activity of cholinesterases was determined according to Ellman et al. (1961), adapted for microplate readers by Sandahl and Jenkins (2002), and using the carbamate eserine (physostigmine) as an inhibitor. Final units of enzyme activity were $\mathrm{nmol} / \mathrm{min} / \mathrm{mg}$ protein. MT concentrations and cholinesterase activity were normalized to total protein concentration following the method of Bradford (1976), using bovine serum albumin as a standard ( $1 \% \mathrm{BSA}$, or $10 \mathrm{mg} / \mathrm{mL})$.

\subsection{Statistical analysis}

Normality of data was tested (and confirmed) by the Shapiro Wilks test; and homogeneity of variance was confirmed by the Levene test. Biota-Sediment Accumulation Factors (BSAFs) were calculated according to Thomann et al. (1995) by dividing tissue metal concentrations by sediment metal concentrations (all on dry weight basis). The degree of correlation between metal concentrations in sediments and metal concentration in tissues was analyzed by Pearson correlation. Additionally, Principal Component Analysis (PCA) was performed to reduce inter-correlation between environmental parameters and to explore statistical associations between metal concentrations in sediments and tissues with the physical-chemical variables (temperature, salinity, $\mathrm{DO}$ and $\mathrm{pH}$ ) measured in field. For analyzing variance in biomarker measurements, a three-way ANOVA was performed (with tissue type, location, and sampling date as fixed treatments), followed by a two-way ANOVA and a post hoc analysis (Tukey HSD), to test for differences between biomarker responses in the two tissues (gills and digestive gland), the five different sampling stations (Taganga, Santa Marta Marina, Ctg-1, Ctg-2 and Barú) and the three different sampling occasions (October 2012; March 2013 and October 2013). For an integrated analysis, PCA was performed on the entire biomarker and environmental parameter dataset, to decompose the variance contributions of metal concentrations (in tissues and sediments), water physical-chemical parameters and tissue biomarkers among four of the five sampling stations (Taganga, Marina, Barú, and Ctg-2, excluding Ctg-1) and two sampling dates (October of 2012 and March 2013, excluding October 2013), combined with a Pearson correlation analysis to quantify the degree of correlation between biomarkers an metals concentrations in tissues and sediments. Furthermore, to explore the relative variance contributions of physical-chemical water parameters, on the one hand, and tissue and sediment concentrations, on the other hand, a second set of PCAs was performed to consolidate individual physical-chemical variables and metal variables among separate principal component axes, to relate with biomarker responses. Stepwise multiple (linear) regression analysis (SWMR) was used to define a subset of significant predictor variables $\left(\mathrm{X}_{\mathrm{i}}\right)$ from the pool of physical-chemical parameters and tissue metal concentrations, to estimate respective biomarker responses as criterion variables $\left(Y_{i}\right.$, Sokal and Rohlf, 1995; Zar, 2010). For multivariate statistical analysis we used the Stat Graphics Centurion XVI and XLSTAT packages.

\section{Results}

\subsection{Physical-chemical parameters and contaminant analysis}

Table 7 summarizes the physical-chemical water parameters analyzed. Salinity fluctuated between 23.9 and 37.0 psu, with lowest salinity for Barú, while Taganga and Marina (both near the city of Santa Marta) had the highest salinity (37.0 psu). Water pH ranged between pH 7.8-8.4 and did not fluctuate significantly between stations and sampling dates, with Ctg-2 in March 2013 presenting the lowest pH (7.8) and Barú and Taganga the highest $\mathrm{pH}$ (8.4). Water temperature fluctuated significantly between stations and sampling dates, with lower temperatures prevailing in March 2013, except for Santa Marta-Marina where temperature was similar for both sampling dates. Dissolved oxygen varied between 2.5-7.2 mg/L, with lowest concentrations for Ctg-2 (on both sampling dates) and highest concentrations in Santa Marta-Taganga Bay. 
Table 7

Physical-chemical parameters (salinity, pH, temperature [Temp] and dissolved oxygen [DO]) in surface water at 5 stations (Taganga, Santa Marta- Marina, Barú, Ctg-1 and Ctg-2) in October 2012 and March 2013. Monthly surface salinity averages were extrapolated from Vivas- Aguas et al. (2012, 2015).

\begin{tabular}{|c|c|c|c|c|c|}
\hline \multirow[t]{2}{*}{ STATIONS } & \multirow[t]{2}{*}{ DATES } & \multicolumn{4}{|c|}{ PHYSICAL-CHEMICAL PARAMETERS } \\
\hline & & $\begin{array}{l}\text { Salinity } \\
\text { (psu) }\end{array}$ & $\mathrm{pH}$ & $\begin{array}{l}\text { Temp } \\
\left({ }^{\circ} \mathrm{C}\right)\end{array}$ & $\begin{array}{l}\text { DO } \\
\text { (mg/L) }\end{array}$ \\
\hline \multirow[t]{2}{*}{ TAGANGA } & Oct-12 & 36.0 & 8.4 & 30.3 & 7.2 \\
\hline & Mar-13 & 37.0 & 8.1 & 27.3 & 7.0 \\
\hline \multirow[t]{2}{*}{ MARINA } & Oct-12 & 35.5 & 8.3 & 29.4 & 5.3 \\
\hline & Mar-13 & 37.0 & 8.0 & 29.0 & 4.4 \\
\hline \multirow[t]{2}{*}{ BARÚ } & Oct-12 & 30.0 & 8.4 & 31.7 & 5.8 \\
\hline & Mar-13 & 33.0 & 8.4 & 27.5 & 5.5 \\
\hline \multirow[t]{2}{*}{ CTG-1 } & Oct-12 & 28.0 & 8.2 & 31.5 & 5.0 \\
\hline & Mar-13 & 33.0 & 8.2 & 27.8 & 5.0 \\
\hline \multirow[t]{2}{*}{ CTG-2 } & Oct-12 & 25.0 & 8.2 & 31.0 & 2.5 \\
\hline & Mar-13 & 30.0 & 7.8 & 28.7 & 2.5 \\
\hline
\end{tabular}

Organophosphate and organochlorine pesticide concentrations in sediments were below detection limits for all 42 compounds analyzed (see Tables 13 and 14 in Supplemental Data), except for pp-DDE in Santa Marta-Marina Oct 2012 (2 ng/g), Ctg-2 Oct 2012 (5 ng/g) and Barú March $2013(2 \mathrm{ng} / \mathrm{g})$. Likewise, OP and OCP (DDTs and HCHs) concentrations in tissues were below detection limits $(2-50 \mathrm{ng} / \mathrm{g}$ for OCPs and $2 \mathrm{ng} / \mathrm{g}$ for chlorpyrifos). Metal concentrations of $\mathrm{As}, \mathrm{Cd}, \mathrm{Cr}, \mathrm{Cu}, \mathrm{Hg}, \mathrm{Ni}, \mathrm{Pb}, \mathrm{Sn}$ and $\mathrm{Zn}$ in sediments and oyster tissues collected in Oct 2012 and Mar 2013 are reported in Table 8 (note: no sediment metal data available for Oct 2013 due to loss of sample). 
Table 8

Metal concentrations ( $\mathrm{Sn}, \mathrm{Hg}, \mathrm{Pb}, \mathrm{Cr}, \mathrm{Cu}, \mathrm{Zn}, \mathrm{As}, \mathrm{Cd}$ and $\mathrm{Ni}$ ) in sediments and oyster tissue from 5 stations (Taganga, Santa Marta-Marina, Barú, Ctg-1 and Ctg-2) in October 2012 and March 2013. Tissue metal concentrations from Aguirre-Rubi et al. (2017). TEL = toxic effects level,

PEL = probable effects level for marine sediments, as proposed by Buchman (2008), based on MacDonald et al. (1996), MWP-L (low), M (medium) and $\mathrm{H}$ (high) = envelope of tissue metal concentrations for $C$. virginica from NOAA Mussel Watch Program (Kimbrough et al. 2008).

\begin{tabular}{|c|c|c|c|c|c|c|c|c|c|c|c|}
\hline \multirow[t]{3}{*}{ STATIONS } & \multirow[t]{3}{*}{ DATES } & \multicolumn{10}{|c|}{ METALS ( $\mu \mathrm{g} / \mathrm{g} \mathrm{dw})$} \\
\hline & & \multicolumn{2}{|l|}{ Sn 120} & \multicolumn{2}{|l|}{$\mathrm{Hg} 202$} & \multicolumn{2}{|l|}{$\mathrm{Pb} 208$} & \multicolumn{2}{|l|}{ Cr 52} & \multicolumn{2}{|l|}{ Cu 63} \\
\hline & & Tissue & Sediment & Tissue & Sediment & Tissue & Sediment & Tissue & Sediment & Tissue & Sediment \\
\hline \multirow[t]{2}{*}{ TAGANGA } & Oct-12 & 0.09 & 1.06 & 0.18 & 0.01 & 0.90 & 4.10 & 8.64 & 50 & 209.90 & 30.00 \\
\hline & $\begin{array}{l}\text { Mar- } \\
13\end{array}$ & 0.06 & 0.19 & 0.11 & 0.01 & 0.79 & 2.90 & 6.39 & 55 & 113.04 & 26.00 \\
\hline \multirow[t]{2}{*}{ MARINA } & Oct-12 & 1.24 & 1.14 & 0.17 & 0.04 & 0.49 & 9.80 & 0.95 & 31 & 343.16 & 30.00 \\
\hline & $\begin{array}{l}\text { Mar- } \\
13\end{array}$ & 1.63 & 1.14 & 0.13 & 0.04 & 0.64 & 10.10 & 1.22 & 31 & 465.80 & 60.00 \\
\hline \multirow[t]{2}{*}{ BARÚ } & Oct-12 & 0.02 & 1.00 & 0.10 & 0.05 & 0.34 & 6.10 & 1.07 & 15 & 58.30 & 25.00 \\
\hline & $\begin{array}{l}\text { Mar- } \\
13\end{array}$ & 0.07 & 0.29 & 0.04 & 0.05 & 0.37 & 6.20 & 2.11 & 14.6 & 66.45 & 25.00 \\
\hline \multirow[t]{2}{*}{ CTG-1 } & Oct-12 & 0.22 & n. a. & 0.09 & n. a. & 0.59 & n. a. & 9.14 & n. a. & 143.42 & n. a. \\
\hline & $\begin{array}{l}\text { Mar- } \\
13\end{array}$ & 0.00 & 0.31 & 0.07 & 0.17 & 0.15 & 4.10 & 0.23 & 8.7 & 54.89 & 16.90 \\
\hline \multirow[t]{2}{*}{ CTG-2 } & Oct-12 & 1.05 & 0.53 & 0.07 & 0.07 & 0.75 & 6.40 & 2.58 & 18.7 & 296.68 & 65.00 \\
\hline & $\begin{array}{l}\text { Mar- } \\
13\end{array}$ & 0.11 & 0.20 & 0.04 & 0.02 & 0.22 & 2.70 & 0.28 & 5.1 & 38.72 & 6.80 \\
\hline \multicolumn{2}{|c|}{ TEL (sediment) } & & 0.048 & & 0.13 & & 30.24 & & 52.3 & & 18.7 \\
\hline \multicolumn{2}{|c|}{ PEL (sediment) } & & n. a. & & 0.7 & & 112 & & 160 & & 108 \\
\hline \multicolumn{2}{|c|}{ MWP-L (tissue) } & \multicolumn{2}{|l|}{$0.0-0.2$} & \multicolumn{2}{|l|}{$\begin{array}{l}0.0- \\
0.07\end{array}$} & \multicolumn{2}{|l|}{$\begin{array}{l}0.1- \\
0.5\end{array}$} & \multicolumn{2}{|l|}{ n. a. } & \multicolumn{2}{|l|}{$7-211$} \\
\hline \multicolumn{2}{|c|}{ MWP-M (tissue) } & \multicolumn{2}{|l|}{$0.3-0.6$} & \multicolumn{2}{|l|}{$\begin{array}{l}0.08- \\
0.15\end{array}$} & \multicolumn{2}{|l|}{$\begin{array}{l}0-6- \\
0.9\end{array}$} & \multicolumn{2}{|l|}{ n. a. } & \multicolumn{2}{|l|}{$\begin{array}{l}212- \\
636\end{array}$} \\
\hline \multicolumn{2}{|c|}{ MWP-H (tissue) } & $0.7-1.9$ & & $\begin{array}{l}0.16- \\
0.33\end{array}$ & & $\begin{array}{l}1.0- \\
2.2\end{array}$ & & n. a. & & $\begin{array}{l}637- \\
1660\end{array}$ & \\
\hline STATIONS & DATES & METALS & $\mathrm{Jg} / \mathrm{g} \mathrm{dw})$ & & & & & & & & \\
\hline & & Zn 66 & & As 75 & & Cd 111 & & Ni 60 & & & \\
\hline & & Tissue & Sediment & Tissue & Sediment & Tissue & Sediment & Tissue & Sediment & & \\
\hline TAGANGA & Oct-12 & 4178.18 & 41.00 & 15.67 & 3.00 & 2.15 & 0.06 & 3.20 & 34.00 & & \\
\hline & $\begin{array}{l}\text { Mar- } \\
13\end{array}$ & 1900.18 & 23.00 & 33.03 & 4.90 & 1.14 & 0.05 & 2.34 & 28.00 & & \\
\hline MARINA & Oct-12 & 4053.83 & 91.00 & 9.80 & 2.20 & 0.73 & 0.10 & 0.61 & 13.10 & & \\
\hline & $\begin{array}{l}\text { Mar- } \\
13\end{array}$ & 3541.70 & 99.00 & 10.60 & 2.20 & 0.76 & 0.09 & 0.64 & 13.30 & & \\
\hline BARÚ & Oct-12 & 478.37 & 32.00 & 6.89 & 11.00 & 22.86 & 0.72 & 0.98 & 15.00 & & \\
\hline & $\begin{array}{l}\text { Mar- } \\
13\end{array}$ & 1271.46 & 36.00 & 6.87 & 8.90 & 2.54 & 0.97 & 0.41 & 13.90 & & \\
\hline CTG-1 & Oct-12 & 2663.11 & n. a. & 7.62 & n. a. & 9.31 & n. a. & 0.91 & n. a. & & \\
\hline & $\begin{array}{l}\text { Mar- } \\
13\end{array}$ & 488.58 & 34.00 & 7.04 & 4.00 & 15.88 & 0.55 & 0.43 & 11.30 & & \\
\hline CTG-2 & Oct-12 & 3390.19 & 34.00 & 5.96 & 8.50 & 10.72 & 0.13 & 1.61 & 7.60 & & \\
\hline
\end{tabular}




\begin{tabular}{|c|c|c|c|c|c|c|c|c|c|c|c|}
\hline \multirow[t]{3}{*}{ STATIONS } & \multirow[t]{3}{*}{ DATES } & \multicolumn{10}{|c|}{ METALS $(\mu \mathrm{g} / \mathrm{g} \mathrm{dw})$} \\
\hline & & \multicolumn{2}{|l|}{ Sn 120} & \multicolumn{2}{|l|}{$\mathrm{Hg} 202$} & \multicolumn{2}{|l|}{$\mathrm{Pb} 208$} & \multicolumn{2}{|l|}{ Cr 52} & \multicolumn{2}{|l|}{ Cu 63} \\
\hline & & Tissue & Sediment & Tissue & Sediment & Tissue & Sediment & Tissue & Sediment & Tissue & Sediment \\
\hline & $\begin{array}{l}\text { Mar- } \\
13\end{array}$ & 718.69 & 28.00 & 6.48 & 2.00 & 3.43 & 0.37 & 0.49 & 3.90 & & \\
\hline \multicolumn{2}{|c|}{ TEL (sediment) } & & 124 & & 7.24 & & 0.68 & & 15.9 & & \\
\hline \multicolumn{2}{|c|}{ PEL (sediment) } & & 271 & & 41.6 & & 4.21 & & 42.8 & & \\
\hline \multicolumn{2}{|c|}{ MWP-L (tissue) } & $99-3260$ & & $3-11$ & & $0-3$ & & $\begin{array}{l}0.7- \\
1.6\end{array}$ & & & \\
\hline \multicolumn{2}{|c|}{ MWP-M (tissue) } & $\begin{array}{l}3261- \\
9165\end{array}$ & & $12-22$ & & $4-6$ & & $\begin{array}{l}1,7- \\
2,5\end{array}$ & & & \\
\hline \multicolumn{2}{|c|}{ MWP-H (tissue) } & $\begin{array}{l}9166- \\
18950\end{array}$ & & $23-57$ & & $7-15$ & & $\begin{array}{l}2,6- \\
4,9\end{array}$ & & & \\
\hline
\end{tabular}

To compare measured sediment metal concentrations with sediment quality guidelines (SQG), the Probable Effect Level (PEL) and the Threshold Effect Level (TEL) values proposed by Buchman (2008) were used for guidance. Sediment concentrations of all 9 metals analyzed were below their respective PEL (Table 8). For Pb and Zn, sediment concentrations for all locations and sampling occasions were also below the respective TEL $(30.2 \mu \mathrm{g} / \mathrm{g}$ for Pb and $124 \mu \mathrm{g} / \mathrm{g}$ for Zn). The TEL for $\mathrm{Hg}$ was exceeded in Ctg-1, in March 2013 and $\mathrm{Cr}$ in Taganga, in March 2013. Sediment Ni followed a pattern like $\mathrm{Cr}$, with concentrations close to the TEL $(15.9 \mu \mathrm{g} / \mathrm{g})$ for most stations, but with two exceedances (Taganga, Oct 2012 and Mar 2013). Sediment As exceeded the TEL (7.2 $\mu \mathrm{g} / \mathrm{g}$ ) on three occasions (Barú, 2012 and 2013, and Ctg-2, Oct 2012), showing a similar pattern to $\mathrm{Cd}$, which exceeded TEL $(0.68 \mu \mathrm{g} / \mathrm{g})$ in two instances (Barú 2012 and Barú 2013). In marked contrast, sediment Sn exceeded the TEL of $0.048 \mu \mathrm{g} / \mathrm{g}$ in all locations and on all sampling occasions, with highest concentrations $(1.14 \mu \mathrm{g} / \mathrm{g})$ in Santa Marta

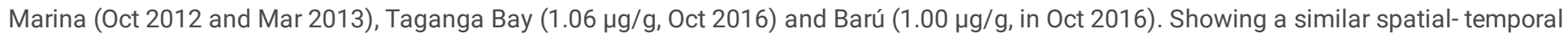
pattern to Sn, sediment Cu concentrations regularly exceeded the TEL of $18.7 \mu \mathrm{g} / \mathrm{g}$, except, on two occasions: Ctg-2 (March 2013) and Ctg-1 in March 2013 (no data for Oct 2012), with maximum concentrations of approximately $60 \mu \mathrm{g} / \mathrm{g}$ in Ctg-2 (Oct 2012) and Santa Marta Marina (Mar 2013). Pearson correlation analysis revealed significant positive correlation between sediment metal concentrations for $\mathrm{Pb}, \mathrm{Sn}, \mathrm{Zn}, \mathrm{Ni}$ and $\mathrm{Cr}(\mathrm{p}<0.05)$, specifically between $\mathrm{Sn}$ and $\mathrm{Pb}$ and $\mathrm{Zn}\left(\mathrm{r}_{\text {Pearson }}=0.71, \mathrm{p}=0.031 ; r_{\text {Pearson }}=0.72, \mathrm{p}=0.028\right.$, respectively), $\mathrm{Zn}$ and $\mathrm{Pb}\left(\mathrm{r}_{\mathrm{Pearson}}\right.$ $=0.89, \mathrm{p}=0.001)$ and $\mathrm{Ni}$ and $\mathrm{Cr}\left(\mathrm{r}_{\text {Pearson }}=0.87, \mathrm{p}=0.002\right)$.

Metal and organic contaminants concentrations in bivalve tissues have been reported in a previous publication by us (Aguirre-Rubi et al., 2017), but will be briefly summarized here. To compare metal levels in oyster tissues, whole-tissue concentrations of the US NOAA Mussel Watch Program (MWP, Kimbrough et al., 2008) for the Eastern oyster (Crassostrea virginica) were used, excluding Cr, for which no reference concentrations were available. Seven of the 8 metals used for this comparison had tissue concentrations well below the respective MWP-H ("high") range, except for Cd, which exceeded the threshold concentration for "high" (15 $\mu \mathrm{g} / \mathrm{g}$ ) on two occasions (Barú- Oct 2013, 22.86 $\mu \mathrm{g} / \mathrm{g}$ dw) and Ctg-1- Mar 2013, (15.88 $\mu \mathrm{g} / \mathrm{g} \mathrm{dw}$ ) and MWP-M ("medium") for two other occasions (Ctg-1- Dec 2012 and Cgt-2- Oct 2012). Tissue concentrations for all other metals were generally below the MWP-L ("low”) range ( $\mathrm{Cu}, \mathrm{Pb}, \mathrm{Zn}$ for all stations), with the exception of $\mathrm{Sn}$ for Marina (Dec 2012 and Mar 2013) and Ctg-2(Oct 2012), As (Taganga Oct 2012), Ni (Taganga-Oct 2012) and Hg (Taganga Oct 2012, Marina Oct 2012), for which tissue concentrations were in the "medium" range. Furthermore, tissue concentrations of Cd, $\mathrm{Hg}, \mathrm{Pb}$ were compared to the national guideline of the Colombian Ministry of Health and Social Protection (Resolution 122 of January 26, 2012), which establishes the maximum limit for metals in bivalves for human consumption in Colombia. For $\mathrm{Hg}$ and $\mathrm{Pb}$, tissue concentrations were below the limits established by the Resolution on all occasions $(0.5 \mu \mathrm{g} / \mathrm{g}$ for $\mathrm{Hg}$ and $1.5 \mu \mathrm{g} / \mathrm{g}$ for $\mathrm{Pb})$. In contrast, $\mathrm{Cd}$ tissue concentrations were above the limit $(1.0 \mu \mathrm{g} / \mathrm{g}$ ) for all stations except for Santa Marta Marina (both years). No permissible tissue levels in bivalves have been defined for Sn, $\mathrm{Cr}, \mathrm{Cu}, \mathrm{Zn}, \mathrm{As}$ and $\mathrm{Ni}$ in Colombia.

To estimate the bioaccumulation of metals in oyster tissue in relation to surrounding sediments, we calculated the Biota-Sediment Accumulation Factor (BSAF, sensu Thomann et al. 1995), by dividing the tissue concentration for a given metal by its corresponding sediment concentration (Table 9). BSAF values greater than 1 indicate bioaccumulation in tissues with respect to sediment, whereas values less than 1 indicate no apparent bioaccumulation. 
Table 9

Biota-Sediment Accumulation Factor (BSAFs) for $\mathrm{Sn}, \mathrm{Hg}, \mathrm{Pb}, \mathrm{Cr}, \mathrm{Cu}, \mathrm{Zn}, \mathrm{As}, \mathrm{Cd}$ and $\mathrm{Ni}$ in oyster tissues versus surface sediments from 5 stations (Taganga, Santa Marta-Marina, Barú, Ctg-1 and Ctg-2), collected during October 2012 and March 2013. BSAF values greater than 1 are marked in boldface.

\begin{tabular}{|c|c|c|c|c|c|c|c|c|c|c|}
\hline STATION & DATE & BSAF Sn & BSAF Hg & BSAF Pb & BSAF Cr & BSAF Cu & BSAF Zn & BSAF As & BSAF Cd & BSAF Ni \\
\hline \multirow[t]{2}{*}{ Taganga } & Oct 2012 & 0.08 & 18.07 & 0.22 & 0.17 & 7.00 & 101.91 & 5.22 & 33.58 & 0.09 \\
\hline & Mar 2013 & 0.30 & 10.81 & 0.27 & 0.12 & 4.35 & 82.62 & 6.74 & 21.53 & 0.08 \\
\hline \multirow[t]{2}{*}{ Marina } & Oct 2012 & 1.09 & 3.95 & 0.05 & 0.03 & 11.44 & 44.55 & 4.46 & 7.23 & 0.05 \\
\hline & Mar 2013 & 1.43 & 3.05 & 0.06 & 0.04 & 7.76 & 35.77 & 4.82 & 8.47 & 0.05 \\
\hline \multirow[t]{2}{*}{ Barú } & Oct 2012 & 0.02 & 1.94 & 0.06 & 0.07 & 2.33 & 14.95 & 0.63 & 31.75 & 0.07 \\
\hline & Mar 2013 & 0.24 & 0.85 & 0.06 & 0.14 & 2.66 & 35.32 & 0.77 & 2.62 & 0.03 \\
\hline CTG-1 & Mar 2013 & 0.00 & 0.40 & 0.04 & 0.03 & 3.25 & 14.37 & 1.76 & 28.88 & 0.04 \\
\hline \multirow[t]{2}{*}{ CTG-2 } & Oct 2012 & 1.98 & 0.98 & 0.12 & 0.14 & 4.56 & 99.71 & 0.70 & 81.83 & 0.21 \\
\hline & Mar 2013 & 0.55 & 1.68 & 0.08 & 0.06 & 5.69 & 25.67 & 3.24 & 9.27 & 0.13 \\
\hline
\end{tabular}

Highest BSAFs, approaching or exceeding 100, were observed for Zn and Cd. In contrast, Cu As, and Hg had intermediate accumulation factors of 1-10, whereas $\mathrm{Sn}, \mathrm{Pb}, \mathrm{Cr}$ and $\mathrm{Ni}$, had BSAFs around or less than 1, indicating negligible bioaccumulation in oyster tissues. Pearson correlation analysis gave positive correlations between tissue metals for $\mathrm{Cr}$ and $\mathrm{Pb}\left(\mathrm{r}_{\text {Pearson }}=0.82, \mathrm{p}=0.007\right), \mathrm{Cu}$ and $\mathrm{Sn}\left(\mathrm{r}_{\mathrm{Pearson}}=0.94, \mathrm{p}=\right.$ 0.000), and Zn vs. Sn, Hg, Pb and $\mathrm{Cu}\left(r_{\text {Pearson }}=0.68, p=0.042 ; r_{\text {Pearson }}=0.75, p=0.019 ; r_{\text {Pearson }}=0.77, p=0.015\right.$ and $r_{P e a r s o n}=0.84, p=0.004$, respectively), As and $\mathrm{Cr}\left(r_{\text {Pearson }}=0.69, \mathrm{p}=0.036\right)$ and $\mathrm{Ni}$ vs. $\mathrm{Pb}$ and $\mathrm{Cr}\left(\mathrm{r}_{\text {Pearson }}=0.83, \mathrm{p}=0.005\right.$ and $\mathrm{r}_{\text {Pearson }}=0.95, \mathrm{p}=0.000$, respectively). Pearson correlation analysis revealed significant positive correlations between the concentration of $\mathrm{Cr}$, $\mathrm{Cu}$ and $\mathrm{Ni}$ in tissues with the corresponding concentration in sediments ( $r_{\text {Pearson }}=0.84, p=0.004 ; r_{\text {Pearson }}=0.81, p=0.008 ; r_{\text {Pearson }}=0.83, p=0.005$ respectively), whereas no significant correlation between tissue metals and sediment metals was evident for Hg, As and Cd ( $p>0.05$, see Supplemental data, Table 15).

\subsection{Biomarkers}

Average metallothionein-like protein concentrations and cholinesterase activity in oyster digestive gland and gill tissue (arithmetic mean of 3 replicates per tissue, per site, or per date, respectively) are presented in Table 10. 
Table 10

Mean biomarker levels (mean $\pm 1 \mathrm{SE}$ ) in oyster digestive gland and gill tissue, for five stations (Taganga, Marina, Barú, Ctg-1 and Ctg-2), for three sampling occasions (October 2012, March 2013, and October 2013)

\begin{tabular}{|c|c|c|c|c|c|c|c|}
\hline \multirow[t]{2}{*}{ Biomarker } & \multirow[t]{2}{*}{ Tissue } & \multirow[t]{2}{*}{ Date } & \multicolumn{5}{|l|}{ Stations } \\
\hline & & & Marina & Taganga & Ctg-1 & Ctg-2 & Barú \\
\hline $\begin{array}{l}\text { Metallothionein-like protein } \\
\text { concentration, }\end{array}$ & $\begin{array}{l}\text { Digestive } \\
\text { Gland }\end{array}$ & $\begin{array}{l}\text { Oct- } \\
12\end{array}$ & $6.8+/-0.7$ & $9.9+/-3.9$ & $5.3+/-0.4$ & $6.5+/-0.4$ & $6.8+/-1.5$ \\
\hline \multirow{5}{*}{$\begin{array}{l}\text { MT } \\
\text { ( } \mu \mathrm{g} \mathrm{MT/mg} \mathrm{protein)}\end{array}$} & & $\begin{array}{l}\text { Mar- } \\
13\end{array}$ & $3.6+/-0.6$ & $6.4+/-1.0$ & $5.9+/-0.9$ & $3.4+/-0.8$ & $5.4+/-0.9$ \\
\hline & & $\begin{array}{l}\text { Oct- } \\
13\end{array}$ & $\begin{array}{l}15.7+/- \\
2.8\end{array}$ & $9.6+/-1.4$ & $14.0+/-3.4$ & $\begin{array}{l}13.6+/- \\
1.0\end{array}$ & $8.5+/-1.5$ \\
\hline & Gills & $\begin{array}{l}\text { Oct- } \\
12\end{array}$ & $3.1+/-0.3$ & $4.0+/-1.1$ & $5.5+/-1.6$ & $6.5+/-2.5$ & $8.8+/-0.5$ \\
\hline & & $\begin{array}{l}\text { Mar- } \\
13\end{array}$ & $1.7+/-0.2$ & $3.7+/-0.6$ & $5.6+/-0.3$ & $2.3+/-0.3$ & $5.8+/-1.6$ \\
\hline & & $\begin{array}{l}\text { Oct- } \\
13\end{array}$ & $5.3+/-1.8$ & $4.4+/-0.9$ & $2.8+/-1.4$ & $9.0+/-0.5$ & $9.3+/-0.3$ \\
\hline \multirow{6}{*}{$\begin{array}{l}\text { Total Cholinesterase activity, } \\
\text { T-ChE } \\
\text { (nmol/min/mg protein) }\end{array}$} & $\begin{array}{l}\text { Digestive } \\
\text { Gland }\end{array}$ & $\begin{array}{l}\text { Oct- } \\
12\end{array}$ & $\begin{array}{l}23.7+/- \\
5.1\end{array}$ & $49.2+/-9.8$ & $26.9+/-3.3$ & $\begin{array}{l}58.1+/- \\
9.9\end{array}$ & $\begin{array}{l}21.1+/- \\
2.8\end{array}$ \\
\hline & & $\begin{array}{l}\text { Mar- } \\
13\end{array}$ & $\begin{array}{l}16.4+/- \\
3.5\end{array}$ & $22.0+/-3.1$ & $72.4+/-4.3$ & $\begin{array}{l}18.2+/- \\
2.1\end{array}$ & $\begin{array}{l}15.1+/- \\
2.2\end{array}$ \\
\hline & & $\begin{array}{l}\text { Oct- } \\
13\end{array}$ & $\begin{array}{l}24.3+/- \\
2.9\end{array}$ & $23.2+/-2.5$ & $26.2+/-8.7$ & $\begin{array}{l}17.5+/- \\
4.8\end{array}$ & $\begin{array}{l}19.7+/- \\
3.3\end{array}$ \\
\hline & Gills & $\begin{array}{l}\text { Oct- } \\
12\end{array}$ & $\begin{array}{l}52.4+/- \\
0.3\end{array}$ & $\begin{array}{l}61.6+/- \\
10.5\end{array}$ & $44.3+/-6.9$ & $\begin{array}{l}45.4+/- \\
5.1\end{array}$ & $\begin{array}{l}32.2+/- \\
4.4\end{array}$ \\
\hline & & $\begin{array}{l}\text { Mar- } \\
13\end{array}$ & $\begin{array}{l}38.9+/- \\
6.4\end{array}$ & $14.5+/-1.8$ & $69.2+/-8.5$ & $\begin{array}{l}16.5+/- \\
2.9\end{array}$ & $\begin{array}{l}20.5+/- \\
2.7\end{array}$ \\
\hline & & $\begin{array}{l}\text { Oct- } \\
13\end{array}$ & $\begin{array}{l}51.6+/- \\
1.5\end{array}$ & $28.7+/-5.2$ & $\begin{array}{l}68.6+/- \\
12.3\end{array}$ & $\begin{array}{l}44.8+/- \\
3.2\end{array}$ & $\begin{array}{l}23.2+/- \\
8.5\end{array}$ \\
\hline $\begin{array}{l}\text { Eserine resistant Cholinesterase } \\
\text { activity, }\end{array}$ & $\begin{array}{l}\text { Digestive } \\
\text { Gland }\end{array}$ & $\begin{array}{l}\text { Oct- } \\
12\end{array}$ & $\begin{array}{l}11.1+/- \\
4.2\end{array}$ & $19.5+/-7.9$ & $3.6+/-1.4$ & $6.4+/-9.6$ & $5.8+/-1.8$ \\
\hline \multirow{5}{*}{$\begin{array}{l}\text { Er-ChE } \\
\text { (nmol/min/mg protein) }\end{array}$} & & $\begin{array}{l}\text { Mar- } \\
13\end{array}$ & $\begin{array}{l}10.1+/- \\
2.9\end{array}$ & $8.2+/-1.1$ & $13.7+/-2.9$ & $5.7+/-1.5$ & $8.5+/-2.4$ \\
\hline & & $\begin{array}{l}\text { Oct- } \\
13\end{array}$ & $9.9+/-3.7$ & $7.2+/-3.1$ & $13.8+/-6.6$ & $5.6+/-4.6$ & $\begin{array}{l}11.5+/- \\
2.8\end{array}$ \\
\hline & Gills & $\begin{array}{l}\text { Oct- } \\
12\end{array}$ & $\begin{array}{l}41.1+/- \\
0.6\end{array}$ & $43.2+/-7.9$ & $26.4+/-3.9$ & $\begin{array}{l}19.3+/- \\
3.4\end{array}$ & $\begin{array}{l}21.1+/- \\
5.2\end{array}$ \\
\hline & & $\begin{array}{l}\text { Mar- } \\
13\end{array}$ & $\begin{array}{l}22.0+/- \\
3.3\end{array}$ & $6.7+/-2.1$ & $29.2+/-5.0$ & $9.4+/-2.0$ & $\begin{array}{l}16.2+/- \\
1.2\end{array}$ \\
\hline & & $\begin{array}{l}\text { Oct- } \\
13\end{array}$ & $\begin{array}{l}35.4+/- \\
2.0\end{array}$ & $21.3+/-2.0$ & $46.8+/-4.2$ & $\begin{array}{l}25.1+/- \\
2.2\end{array}$ & $\begin{array}{l}13.8+/- \\
4.8\end{array}$ \\
\hline $\begin{array}{l}\text { Eserine sensitive Cholinesterase } \\
\text { activity, }\end{array}$ & $\begin{array}{l}\text { Digestive } \\
\text { Gland }\end{array}$ & $\begin{array}{l}\text { Oct- } \\
12\end{array}$ & $\begin{array}{l}12.6 \\
+/-0.9\end{array}$ & $29.7+/-2.6$ & $23.2+/-1.8$ & $\begin{array}{l}51.7+/- \\
1.4\end{array}$ & $\begin{array}{l}15.3+/- \\
1.3\end{array}$ \\
\hline \multirow{5}{*}{$\begin{array}{l}\text { Es-ChE } \\
\text { (nmol/min/mg protein) }\end{array}$} & & $\begin{array}{l}\text { Mar- } \\
13\end{array}$ & $6.2+/-1.3$ & $13.8+/-2.0$ & $58.7+/-1.4$ & $\begin{array}{l}12.5+/- \\
0.8\end{array}$ & $6.6+/-0.7$ \\
\hline & & $\begin{array}{l}\text { Oct- } \\
13\end{array}$ & $\begin{array}{l}14.3+/- \\
1.7\end{array}$ & $16.0+/-1.0$ & $12.4+/-3.3$ & $\begin{array}{l}12.0+/- \\
0.6\end{array}$ & $8.2+/-2.0$ \\
\hline & Gills & $\begin{array}{l}\text { Oct- } \\
12\end{array}$ & $\begin{array}{l}11.3+/- \\
0.6\end{array}$ & $18.5+/-5.6$ & $18.0+/-3.1$ & $\begin{array}{l}26.1+/- \\
3.2\end{array}$ & $\begin{array}{l}11.0+/- \\
3.3\end{array}$ \\
\hline & & $\begin{array}{l}\text { Mar- } \\
13\end{array}$ & $\begin{array}{l}17.0+/- \\
3.1\end{array}$ & $7.9+/-0.3$ & $40.0+/-5.6$ & $7.1+/-1.3$ & $4.3+/-1.5$ \\
\hline & & $\begin{array}{l}\text { Oct- } \\
13\end{array}$ & $\begin{array}{l}16.2+/- \\
0.8\end{array}$ & $7.4+/-3.7$ & $21.8+/-8.2$ & $\begin{array}{l}19.7+/- \\
1.2\end{array}$ & $9.8+/-3.4$ \\
\hline
\end{tabular}


Average MT concentrations were higher in digestive gland than in gills on any given sampling occasion. For digestive gland, the highest MT concentration was $15.7 \mu \mathrm{g} \mathrm{MT/mg} \mathrm{protein} \mathrm{(Santa} \mathrm{Marta} \mathrm{Marina,} \mathrm{October} \mathrm{2013),} \mathrm{and} \mathrm{the} \mathrm{lowest} 3.4 \mu \mathrm{g}$ MT/mg protein (Ctg-2, March 2013). For gills, the highest MT concentration was $9.3 \mu \mathrm{g} \mathrm{MT/mg} \mathrm{protein} \mathrm{(Barú,} \mathrm{October} \mathrm{2013)} \mathrm{and} \mathrm{the} \mathrm{lowest} 1.7 \mu \mathrm{g}$ MT/mg protein (Santa Marta Marina, March 2013).

Activities of total cholinesterase (T-ChE) and eserine-sensitive cholinesterase (Es-ChE) were highest for Ctg-1 station (March 2013 ), both, in digestive gland (72.4 and $58.7 \mathrm{nmol} / \mathrm{min} / \mathrm{mg}$ protein, respectively) as well as in gills (69.2 and $40.0 \mathrm{nmol} / \mathrm{min} / \mathrm{mg} \mathrm{protein}$, respectively). In contrast, highest eserine resistant cholinesterase (Er-ChE) activity was found for Ctg-1, Oct $2013 \mathrm{in} \mathrm{gills} \mathrm{(46.8} \mathrm{nmol/min/mg} \mathrm{protein)} \mathrm{and} \mathrm{was}$ considerably lower in digestive gland, with a maximum of $19.5 \mathrm{nmol} / \mathrm{min} / \mathrm{mg}$ protein, for Taganga, Oct 2012. The lowest T-ChE activity was $15.1 \mathrm{nmol} / \mathrm{min} / \mathrm{mg}$ protein, for digestive gland (Barú, Mar 2013) and $14.5 \mathrm{nmol} / \mathrm{min} / \mathrm{mg}$ protein for gill (Taganga, Mar 2013), while lowest EsChE activity was $6.2 \mathrm{nmol} / \mathrm{min} / \mathrm{mg}$ protein for digestive gland at Santa Marta Marina, Mar 2013 and $4.3 \mathrm{nmol} / \mathrm{min} / \mathrm{mg}$ protein and gill (Barú, Mar 2013), respectively. The lowest Er-ChE activity was $3.6 \mathrm{nmol} / \mathrm{min} / \mathrm{mg}$ protein for digestive gland from Ctg-1, Oct 2012, and 6.7 $\mathrm{nmol} / \mathrm{min} / \mathrm{mg}$ protein for gill from Taganga, Oct 2013.

A three-way ANOVA showed significant interaction among factors: tissues, station, and sampling date for metallothionein-like proteins (MT), total cholinesterase (T-ChE), eserine-resistant cholinesterase (Er-ChE) and eserine-sensitive cholinesterase (Es-ChE, $p<0.05$, see Supplemental Data Table 16). Consequently, it was decided to analyze biomarker data separately for each of the two tissues: A two-way ANOVA, conducted separately for digestive gland biomarker results (with station and date as treatments) revealed significant differences for digestive gland ChE activity between the two factors station and date $(p<0.05)$, except for Er-ChE activity, which was non-significant between dates $(p=0.94)$. For all ChE biomarkers, strong station-date interaction was noted. On the other hand, differences in MT levels between stations for a given sampling date were not strong enough to be considered significant ( $p=0.07)$, even though higher average MT concentrations were noted for the third sampling date (Oct 2013, Fig. 11). For gills, two-way ANOVA confirmed significant differences between stations as well as dates for all four biomarkers ( $p<0.05$, see Supplemental Data, Tables 17 and 18). Strong station-date interaction was noted in all cases.

For MT in digestive gland, post hoc pairwise comparisons (Tukey HSD) did not reveal any significant differences between stations for any of the three sampling dates (while holding date constant, $p>0.05$, Fig. 11). On the other hand, MT concentrations in digestive gland varied temporally, being significantly higher in October 2013 than in March 2013 for Santa Marta Marina $(p=0.002)$ and Ctg-2 ( $p=0.017)$, whereas for the other three stations, the somewhat higher MT levels in October 2013 were not statistically significant. For MT in gills, significant spatial differences were evident during October of 2013 between Ctg-1 vs. Barú and Ctg-2 ( $p<0.05)$. Significant differences in gill MT levels between dates were observed only for Ctg-2 station, namely, between March 2013 and October $2013(p=0.016)$.

For T-ChE activity in digestive gland, post hoc analysis (Tukey HSD) showed significant differences for October 2012 between Ctg-2 vs. Santa Marta Marina, Ctg-1 and Barú; and between Taganga and Barú ( $<<0.05$, Fig. 12). For March 2013, significant differences were found between Ctg-1 vs. Santa Marta Marina, Taganga, Ctg-2 and Barú ( $p<0.05)$, for which the same significant difference in T-ChE activity was also evident for gill tissue. Gill T-ChE activity was also significantly different between Ctg-1 vs. Taganga and Barú in October 2013 ( $p<0.05$ ). Furthermore, significant temporal differences for digestive gland T-ChE activity were evident for Ctg-1 when comparing October 2012 vs. March 2013 and March 2013 vs. October 2013 ( $p=0.0002$ and 0.0001, respectively), for Ctg-2 when comparing October 2012 vs. March 2013 and October 2013 ( $p=0.0007$ and 0.0006, respectively) as well as Taganga (October 2012 vs. March 2013 and October 2012 vs. October 2013 , $p=0.0009$ and 0.049 , respectively). No statistical differences in digestive gland T-ChE activity between dates were observed for the other two sites (Santa Marta Marina and Barú).

For Er-ChE activity in digestive gland, post hoc analysis (Tukey HSD) confirmed spatial differences between Taganga vs. Ctg-1, Ctg-2, and Barú for October 2012 ( $p<0.05$, Fig. 13), while no significant differences between stations were evident for March 2013 and October 2013 ( $p$ $>0.05)$. For Er-ChE activity in gills, significant differences were confirmed between Santa Marta Marina vs. Ctg-2 and Barú; and Taganga vs. Ctg-2 and Barú for October 2012; between Ctg-1 vs. Taganga and Ctg-2 for March 2013, and between Santa Marta Marina vs. Barú, and between Ctg-1 vs. Taganga, Ctg-2 and Barú for October 2013 ( $\mathrm{p}<0.05)$. Significant temporal differences in digestive gland Er-ChE activity were only found for Taganga and Ctg-1 when comparing October 2012 with March 2013 and October 2013 ( $p<0.05$ ). Gill Er-ChE activity varied significantly between October 2012 and March 2013 for Santa Marta Marina $(p=0.0482)$, between October 2012 and March 2013 and between October 2012 and October 2013 for Taganga ( $p=0.0001$ and 0.013, respectively) and between October 2012 and October 2013 for Taganga $(p=0.262)$. No temporal significant differences in Er-ChE activity were evident for Ctg-2and Barú $(p>0.05)$.

Finally, for Es-ChE activity, post hoc analysis (Tukey HSD) showed significant spatial differences during Oct 2012 ( $p<0.05$ ) between Ctg-2vs. Santa Marta Marina, Ctg-1 and Barú for digestive gland, whereas no differences between stations were evident for gills during 2012 (Fig. 14). For March 2013, both digestive gland and gills showed significant differences in Es-ChE activity between Ctg-1 and the other four stations ( $p$ < 0.05). Significant differences in digestive gland Es-ChE activity between sampling dates were confirmed only for Ctg-1, for October 2012 vs. March 2013, and for March 2013 vs. October 2013 ( $p=0.0004$ and $p=0.0001$, respectively) as well as for Ctg-2 (October 2012 vs. March 
2013 and October 2012 vs. October 2013; $p=0.0001$ for both), whereas no significant differences in Es-ChE activity between sampling dates were evident for Santa Marta Marina, Taganga and Barú $(p>0.05)$. No significant spatial differences in ES-ChE activity were evident for Oct 2013 for either of the two tissues.

\subsection{Integrated analysis of biomarker patterns and environmental variables}

For an integrated analysis of biomarker patterns and environmental parameters, Ctg-1 station was excluded (on all sampling occasions) due to the lack of sediment metal data for October 2012 and, furthermore, because T-ChE activity for this station was exceptionally high compared with the other stations, which significantly skewed the correlations with potential environmental predictor variables. By excluding the Ctg-1 biomarker data and limiting the integrated analysis to the four remaining stations (and only two sampling occasions, Oct 2012, and March 2013) the multivariate relationships between biomarkers, metals and physical-chemical parameters became more robust and generalizable. As an unconstrained exploratory analysis, a principal component analysis (PCA) was carried out using the complete dataset (biomarkers, tissue metals, sediment metals and water physical-chemical parameters), to study the variance contributions of biomarkers and environmental variables (Fig. 15, for eigenvectors, factor loadings, factor scores and correlations between variables vs. factors refer to Supplemental Data, Tables 19, 20 and 21).

The PCA resulted in five principal components with eigenvalues > 1, explaining $93.2 \%$ of the variation of the data (PC1: $34.8 \%$, PC2: $23.7 \%$ PC3: 19.8\%, PC4: 11.5\%, and PC5: 5.6\%, Fig. 15). For component PC1, high loadings (and high squared cosine values) were observed for 4 biomarker variables (MT in digestive gland, T-ChE in gills and Er- ChE in digestive gland and gills), 5 tissues metals (Hg, Pb, $\mathrm{Cr}$, Zn and Ni), and 4 sediment metals ( $\mathrm{Sn}, \mathrm{Cr}, \mathrm{Cd}$ and $\mathrm{Ni}$ ), together contributing $73 \%$ of the eigenvalue of $\mathrm{PC} 1$. Cd in sediments presented a high negative factor loading, whereas none of the four physical-chemical parameters ( $T, S \mathrm{pH}, \mathrm{DO}$ ) presented high loadings for PC1. For component PC2, high factor loadings were observed for the biomarker Es- ChE in gills, 3 tissues metals ( $\mathrm{Sn}, \mathrm{Cu}$ and $\mathrm{As}$ ), 2 sediment metals (Hg, Pb and Cu), and DO, together contributing $49 \%$ of the eigenvalue of PC2. For component PC3, high factor loadings were observed for the biomarker Es-ChE in digestive gland, tissue $\mathrm{Cd}$, sediment $\mathrm{Zn}$ and sediment As, as well as 2 physical-chemical parameters (S and T), together contributing $65 \%$ of the eigenvalue of PC3. Components PC4 and PC5 did not contain any significant loadings of biomarker or metal variables, and only component PC4 had a representative contribution of $\mathrm{pH}$.

Stations with high factor loadings for component PC1 were Taganga (Oct 2012), Barú (Mar 2013) and Ctg-2 (Mar 2013), characterized by high variance contributions of MT in digestive gland, T-ChE activity in gills and Er-ChE activity in digestive gland and gills. Taganga (Mar 2013) and Ctg-2 (Oct 2012) had elevated factor loadings for factor PC2, where biomarker variables were represented by Es-ChE activity in gills. Santa Marta Marina, on both sampling occasions (Oct 2012 and March 2013), had high factor loadings for PC3, as did Barú (Oct 2012), where MT in gills, and T- ChE and Es- ChE activity in digestive gland were the biomarker variables with a sizable contribution.

Pearson correlation analysis between biomarkers and physical-chemical parameters showed significant positive correlation only between MT in digestive gland with $\mathrm{pH}\left(\mathrm{r}_{\text {Pearson }}=0.75, \mathrm{p}=0.03\right.$, see Tables 22 and 23 in Supplemental Data). Pearson correlation analysis between biomarkers and sediment metals showed significant positive correlation between $\mathrm{MT}$ in digestive gland with sediment $\mathrm{Ni}\left(\mathrm{r}_{\mathrm{P} \text { earson }}=0.73, \mathrm{p}=\right.$ 0.03); and for MT in gills with sediment As ( $r_{\text {Pearson }}=0.95, p<0.01$. Significant positive correlation was observed between T-ChE activity in gills and sediment $S n$ concentrations $\left(r_{\text {Pearson }}=0.79, p=0.02\right)$, whereas no significant correlation with sediment metals was evident for T-ChE activity in digestive gland. Er-ChE activity in digestive gland correlated positively with sediment Ni $\left(r_{P e a r s o n}=0.74, p=0.03\right)$ whereas Er-ChE activity in gills correlated with sediment $S n\left(r_{\text {Pearson }}=0.80, p=0.015\right)$. Lastly, Es-ChE activity in gills correlated with sediment Cu $\left(r_{P e a r s o n}=\right.$ $0.81, p=0.014$ ). No significant correlation with sediment metals was evident for Es-ChE activity in digestive gland (see Supplemental Data, Table 22).

Pearson correlation analysis between biomarkers and tissue metals showed significant positive correlation between MT in digestive gland with tissue $\mathrm{Cr}\left(r_{\text {Pearson }}=0.73, p=0.03\right)$ as well as tissue Ni $\left(r_{\text {Pearson }}=0.77, p=0.02\right)$; and for MT in gills with Cd $\left(r_{\text {Pearson }}=0.85, p=0.007\right)$. TChE activity in gills, correlated significantly and positively with tissue $\mathrm{Hg}\left(r_{\text {Pearson }}=0.76, p=0.02\right)$ and $Z n\left(r_{P e a r s o n}=0.83, p=0.011\right)$. Likewise, Er-ChE activity in gills also correlated with tissue $\mathrm{Hg}\left(r_{\text {Pearson }}=0.82, p=0.012\right)$ and tissue $Z n\left(r_{P e a r s o n}=0.72, p=0.04\right)$, and Er-ChE activity in digestive gland also correlated significantly with tissue $\mathrm{Hg}\left(r_{\text {Pearson }}=0.76, p=0.027\right)$ as well as with tissue $\mathrm{Cr}\left(r_{\mathrm{Pearson}}=0.70, p=0.05\right)$. No significant correlation with sediment metals was evident for T-ChE activity in digestive gland nor for Es-ChE activity in both tissues (see Supplemental Data, Table 23).

Step-Wise Multiple Regression (SWMR) was performed to determine the best set of predictor variables (Xi, in this case: water physicalchemical parameters and metal concentrations in sediments and tissues) for the observed biomarker patterns ( $Y_{i}=$ "criterion variables"). Two sets of SWMRs were carried out: one set (termed "Regression A") using sediment metal concentrations and water physical-chemical parameters as predictor variables, whereas a second set (termed "Regression B") used tissue metal concentrations and the same water physical-chemical parameters used in Regression A (i.e., pH and DO). SWMR results are shown in Table 11.

Page 11/32 
Table 11

Step-Wise Multiple Regression (SWMR) for biomarkers vs. water physical-chemical parameters and metal concentrations in sediment (Regression A) and physical-chemical parameters and metals in tissue (Regression B). Only best model (and overall significance level, $p$ ) and best predictor variables are presented. Data in bold indicate significant partial regression slopes $(p<0.05)$ of respective predictor variable; Probability for entry: $p<0.15$, probability for removal: $p=0.16$ for all models). For T-ChE in Regression A, no significant predictor variables were found.

\begin{tabular}{|c|c|c|c|c|c|c|c|c|c|}
\hline \multicolumn{10}{|c|}{ Regression A: Environmental parameters: physical-chemical data and sediment metal concentrations } \\
\hline $\begin{array}{l}\text { Biomarker } \\
\left(Y_{i}\right)\end{array}$ & Tissue & Best Model & $\begin{array}{l}\text { Predictor } \\
\text { Variables }\left(\mathbf{X}_{i}\right) \\
\text { in final model }\end{array}$ & \multicolumn{2}{|c|}{$\begin{array}{l}\text { Standard partial } \\
\text { regression coefficient }\end{array}$} & \multicolumn{2}{|c|}{$\begin{array}{l}\text { p-value for partial } \\
\text { regression coefficient }\end{array}$} & $\begin{array}{l}\text { Adjusted } \\
r^{2}\end{array}$ & $\begin{array}{l}\text { Overall } \\
\text { Significance } \\
\text { of Model } \\
(\mathrm{Pr}>\mathrm{F})\end{array}$ \\
\hline \multirow[t]{10}{*}{ MT } & \multirow{4}{*}{$\begin{array}{l}\text { Dig. } \\
\text { Gland }\end{array}$} & \multirow{4}{*}{$\begin{array}{l}\mathrm{pH}+\mathrm{Cd}+ \\
\mathrm{Pb}+\mathrm{Sn}\end{array}$} & $\mathrm{pH}$ & 0.95 & & \multicolumn{2}{|l|}{0.001} & 0.49 & \multirow[t]{4}{*}{0.002} \\
\hline & & & $\mathrm{Cd}$ & -0.52 & & 0.005 & & 0.74 & \\
\hline & & & $\mathrm{Pb}$ & -0.54 & & 0.007 & & 0.95 & \\
\hline & & & Sn & 0.22 & & 0.107 & & 0.97 & \\
\hline & \multirow[t]{6}{*}{ Gills } & \multirow{6}{*}{$\begin{array}{l}\text { As + Temp } \\
+\mathrm{Cu}+\mathrm{pH} \\
+\mathrm{Cd}+\mathrm{DO}\end{array}$} & As & 0.92 & & 0.001 & & 0.89 & \multirow[t]{6}{*}{0.002} \\
\hline & & & Temp & 0.21 & & 0.004 & & 0.94 & \\
\hline & & & $\mathrm{Cu}$ & -0.22 & & 0.004 & & 0.96 & \\
\hline & & & $\mathrm{pH}$ & 0.19 & & 0.007 & & 0.98 & \\
\hline & & & $\mathrm{Cd}$ & -0.18 & & 0.007 & & 0.99 & \\
\hline & & & DO & -0.06 & & 0.019 & & 1.00 & \\
\hline \multirow[t]{2}{*}{ T-ChE } & $\begin{array}{l}\text { Dig. } \\
\text { Gland }\end{array}$ & $\begin{array}{l}\text { No variable } \\
\text { found }\end{array}$ & - & - & & - & & - & - \\
\hline & Gills & Sn & Sn & 0.79 & & 0.018 & & 0.63 & 0.018 \\
\hline \multirow[t]{2}{*}{ Er- ChE } & $\begin{array}{l}\text { Dig. } \\
\text { Gland }\end{array}$ & $\mathrm{Ni}$ & $\mathrm{Ni}$ & 0.74 & & 0.035 & & 0.47 & 0.035 \\
\hline & Gills & Sn & Sn & 0.80 & & 0.015 & & 0.59 & 0.015 \\
\hline \multirow[t]{5}{*}{ Es- ChE } & \multirow{2}{*}{$\begin{array}{l}\text { Dig. } \\
\text { Gland }\end{array}$} & \multirow{2}{*}{$\begin{array}{l}\text { Salinity + } \\
\text { Cr }\end{array}$} & Salinity & -1.32 & & 0.002 & & 0.29 & \multirow[t]{2}{*}{0.005} \\
\hline & & & $\mathrm{Cr}$ & 0.98 & & 0.007 & & 0.82 & \\
\hline & \multirow[t]{3}{*}{ Gills } & \multirow{3}{*}{$\begin{array}{l}\text { Cu + Temp } \\
+\mathrm{Cd}\end{array}$} & $\mathrm{Cu}$ & 0.54 & & 0.033 & & 0.60 & \multirow[t]{3}{*}{0.014} \\
\hline & & & Temp & 0.45 & & 0.044 & & 0.76 & \\
\hline & & & $\mathrm{Cd}$ & -0.31 & & 0.124 & & 0.84 & \\
\hline \multicolumn{10}{|c|}{ Regression B: Environmental parameters: physical-chemical data and tissue metal concentrations } \\
\hline $\begin{array}{l}\text { Biomarker } \\
\left(Y_{i}\right)\end{array}$ & Tissue & Best Model & $\begin{array}{l}\text { Predictor Varia } \\
\text { final model }\end{array}$ & les $\left(X_{i}\right)$ in & $\begin{array}{l}\text { Standard p } \\
\text { regression }\end{array}$ & cient & $\begin{array}{l}\text { p-value for } \\
\text { partial } \\
\text { regression } \\
\text { coefficient }\end{array}$ & $\begin{array}{l}\text { Adjusted } \\
\mathrm{r}^{2}\end{array}$ & $\begin{array}{l}\text { Overall } \\
\text { Significance } \\
\text { of Model } \\
(\mathrm{Pr}>\mathrm{F})\end{array}$ \\
\hline \multirow[t]{6}{*}{ MT } & \multirow{2}{*}{$\begin{array}{l}\text { Dig. } \\
\text { Gland }\end{array}$} & $\mathrm{Ni}+\mathrm{pH}$ & $\mathrm{Ni}$ & & 0.61 & & 0.005 & 0.53 & 0.002 \\
\hline & & & $\mathrm{pH}$ & & 0.58 & & 0.006 & 0.89 & \\
\hline & Gills & $\mathrm{Cd}+\mathrm{pH}+$ & $\mathrm{Cd}$ & & 0.63 & & 0.003 & 0.69 & 0.003 \\
\hline & & & $\mathrm{pH}$ & & 0.57 & & 0.005 & 0.84 & \\
\hline & & & $\mathrm{Hg}$ & & -0.40 & & 0.016 & 0.94 & \\
\hline & & & $\mathrm{Pb}$ & & 0.16 & & 0.13 & 0.97 & \\
\hline T-ChE & Dig. & $\mathrm{Pb}+$ & $\mathrm{Pb}$ & & 0.86 & & 0.004 & 0.33 & 0.007 \\
\hline & & & Salinity & & -0.69 & & 0.010 & 0.81 & \\
\hline
\end{tabular}




\begin{tabular}{|c|c|c|c|c|c|c|c|}
\hline \multicolumn{8}{|c|}{ Regression A: Environmental parameters: physical-chemical data and sediment metal concentrations } \\
\hline & \multirow[t]{2}{*}{ Gills } & \multirow{2}{*}{$\mathrm{Zn}+$ Temp } & $\mathrm{Zn}$ & 0.75 & 0.002 & 0.64 & \multirow[t]{2}{*}{0.002} \\
\hline & & & Temp & 0.48 & 0.012 & 0.89 & \\
\hline \multirow[t]{7}{*}{$\mathrm{Er}-\mathrm{ChE}$} & \multirow{4}{*}{$\begin{array}{l}\text { Dig. } \\
\text { Gland }\end{array}$} & \multirow{4}{*}{$\begin{array}{l}\mathrm{Hg}+\mathrm{Cr}+ \\
\mathrm{As}+\mathrm{Temp}\end{array}$} & $\mathrm{Hg}$ & 0.73 & 0.006 & 0.51 & \multirow[t]{4}{*}{0.007} \\
\hline & & & $\mathrm{Cr}$ & 0.90 & 0.005 & 0.64 & \\
\hline & & & As & -0.83 & 0.010 & 0.76 & \\
\hline & & & Temp & -0.46 & 0.026 & 0.95 & \\
\hline & \multirow[t]{3}{*}{ Gills } & \multirow{3}{*}{$\begin{array}{l}\mathrm{Hg}+\mathrm{As}+ \\
\mathrm{Cr}\end{array}$} & $\mathrm{Hg}$ & 0.89 & 0.002 & 0.62 & \multirow[t]{3}{*}{0.004} \\
\hline & & & As & -0.69 & 0.010 & 0.86 & \\
\hline & & & $\mathrm{Cr}$ & 0.32 & 0.116 & 0.91 & \\
\hline \multirow[t]{8}{*}{ Es- ChE } & \multirow{6}{*}{$\begin{array}{l}\text { Dig. } \\
\text { Gland }\end{array}$} & \multirow{6}{*}{$\begin{array}{l}\text { Salinity + } \\
\mathrm{Pb}+\mathrm{Hg}+ \\
\mathrm{Cd}+\mathrm{Sn}+ \\
\mathrm{pH}\end{array}$} & Salinity & -1.19 & 0.00 & 0.29 & \multirow[t]{6}{*}{0.001} \\
\hline & & & $\mathrm{Pb}$ & 0.61 & 0.00 & 0.92 & \\
\hline & & & $\mathrm{Hg}$ & 0.39 & 0.001 & 0.95 & \\
\hline & & & $\mathrm{Cd}$ & -0.23 & 0.002 & 0.97 & \\
\hline & & & Sn & -0.11 & 0.003 & 1.00 & \\
\hline & & & $\mathrm{pH}$ & -0.008 & 0.038 & 1.00 & \\
\hline & \multirow[t]{2}{*}{ Gills } & \multirow{2}{*}{$\begin{array}{l}\text { Zn+ } \\
\text { Salinity }\end{array}$} & $\mathrm{Zn}$ & 0.86 & 0.011 & 0.34 & \multirow[t]{2}{*}{0.022} \\
\hline & & & Salinity & -0.62 & 0.036 & 0.69 & \\
\hline
\end{tabular}

As shown in Table 11, the best predictor variables for MT in digestive gland were $\mathrm{pH}$, sediment $\mathrm{Cd}, \mathrm{Pb}$ and $\mathrm{Sn}$ (Regression $\mathrm{A}, \mathrm{p}=0.002$ ), and tissue $\mathrm{Ni}$ (Regression $\mathrm{B}, \mathrm{p}=0.002$ ), whereas for MT in gills, the best environmental predictor variables were temperature, $\mathrm{pH}$ and $\mathrm{DO}$, and sediment As, Cu and Cd (Regression A, p = 0.0012) and tissue Cd, $\mathrm{Hg}$ and $\mathrm{Pb}$ (Regression B, $\mathrm{p}=0.003$ ).

In the SWMR of the three ChE components, T-ChE activity in digestive gland was best predicted by tissue $\mathrm{Pb}$ and salinity (Regression $\mathrm{B}, \mathrm{p}=$ 0.007), while no suitable environmental predictor variables relating T-ChE activity in digestive gland with physical-chemical and sediment metals were observed (Regression A). For T-ChE activity in gills, sediment Sn (Regression A, $p=0.018$ ), and temperature and tissue Zn (Regression $\mathrm{B}, \mathrm{p}=0.002$ ) were the best predictor variables. Best predictor variables for $\mathrm{Er}$ - ChE activity in digestive gland were sediment $\mathrm{Ni}$ (Regression $\mathrm{A}, \mathrm{p}=0.035$ ) and tissue $\mathrm{Hg}, \mathrm{Cr}$, As and temperature (Regression $\mathrm{B}, \mathrm{p}=0.007$ ), whereas for Er-ChE activity in gills they were sediment $\mathrm{Sn}$ (Regression $\mathrm{A}, \mathrm{p}=0.015$ ) and tissue $\mathrm{Hg}$, As and $\mathrm{Cr}$ (Regression $\mathrm{B}, \mathrm{p}=0.004$ ). For Es- ChE activity in digestive gland, the best predictor variables were salinity and sediment $\mathrm{Cr}$ (Regression $\mathrm{A}, \mathrm{p}=0.005)$ and salinity, $\mathrm{pH}$, and tissue $\mathrm{Pb}, \mathrm{Hg}, \mathrm{Cd}$ and $\mathrm{Sn}(\operatorname{Regression} \mathrm{B}, \mathrm{p}=$ 0.001). Es-ChE activity in gills was best predicted by temperature and sediment $\mathrm{Cu}$ and $\mathrm{Cd}$ (Regression $\mathrm{A}, \mathrm{p}=0.014$ ), and salinity and tissue Zn (Regression B, $p=0.022$ ), respectively.

To distinguish the differential relationship between oyster biomarkers at the four study sites and the underlying physical-chemical gradient on the one hand, and the suspected metal pollution gradient on the other hand, environmental variables were re-grouped using two sets of PCAs. These served to partition the variance of the environmental parameters along a reduced number of orthogonal axes, thereby greatly reducing the explanatory dimensions while not excluding inter-correlated variables (as is the case in stepwise multiple regression). The first PCA was carried-out using the four physical-chemical parameters of salinity, temperature, $\mathrm{pH}$ and DO (Fig. 16). As before, station Ctg-1 was excluded, for reasons described earlier (for eigenvectors, factor loadings, factor scores and correlations between variables and factors refer to Supplemental Data, Tables 24, 25 and 26).

The PCA of the physical-chemical variables rendered two components with eigenvalues $>1$, explaining $88.5 \%$ of the variation of the data (FQ1: $50.6 \%$ and FQ2: $37.9 \%$, Fig. 16). For FQ1, high loadings (and high squared cosine values) were due to salinity and D0, together contributing $80 \%$ of its eigenvalue. For FQ2, high factor loadings were observed for $\mathrm{pH}$ and temperature, together contributing $87 \%$ of its eigenvalue. The PCA, thus, successfully consolidated the four physical-chemical variables among two principal component axes. Stations with high factor loadings for axis FQ1 were Taganga (Oct 2012 and Mar 2013), Santa Marta Marina (Oct 2012) and Ctg-2 (Oct 2012 and Mar 2013), characterized by high variance contributions of salinity and DO, and Ctg-2 station on both occasions presenting high negative factor loadings. Axis FQ2 received high factor loadings from Santa Marta Marina (Mar 2013) and Barú (Oct 2012), with high variance contributions of pH and temperature. For the station Barú (Mar 2013), the highest factor loading was from component FQ3 (eigenvalue of 0.36 and a $9.0 \%$ 
of contribution to total variance), being the temperature the environmental variable that contributed mostly to the eigenvalue. However, due to its negligible variance contribution, component FQ3 was excluded in subsequent analyses.

Analogously, a second PCA was performed for the combined sediment and tissue metal dataset (Fig. 17, for eigenvectors, factor loadings, factor scores and correlations between variables vs. factors, refer to Supplemental Data, Tables 27, 28 and 29).

The PCA of the metals data showed the conformation of four components with eigenvalues $>1$, explaining $92.6 \%$ of the variation of the data (M1: 40.0\%, M2: 32.8\%, M3: 12.1\%, M4: 7.7\%, Fig. 26). For component M1, high loadings (and high squared cosine values) were observed for sediment $\mathrm{Cr}$, $\mathrm{Ni}$ and $\mathrm{Cd}$ (with negative factor loading) and tissue $\mathrm{Hg}, \mathrm{Pb}, \mathrm{Zn}$ and $\mathrm{Ni}$, together contributing $62.5 \%$ of the eigenvalue of $\mathrm{M} 1$. For component M2, high factor loadings were observed for sediment $\mathrm{Hg}$, Pb, Cu, $\mathrm{Zn}$ and tissue $\mathrm{Sn}, \mathrm{Cu}$, $\mathrm{Cr}$ and As (the latter two tissue metals with negative factor loadings), together contributing $76 \%$ of the eigenvalue of M2. For Component M3, high factor loadings were observed for sediment As and tissue Cd, together contributing $50.6 \%$ of the eigenvalue of M3. Finally, for component M4, only sediment Sn presented high factor loading, contributing $27 \%$ of its eigenvalue.

Stations with high factor loadings (as well as high squared cosine values) for component M1 were Taganga (Oct 2012) and Barú (Oct 2012 and Mar 2013), as well as Ctg-2 (Mar 2013), with the Barú and Ctg-2 stations characterized by negative factor loadings, signifying relatively low concentrations of the contributing metal species (i.e., sediment $\mathrm{Cd}$, $\mathrm{Cr}$, and $\mathrm{Ni}$, and tissue $\mathrm{Hg}, \mathrm{Pb}, \mathrm{Ni}$ and $\mathrm{Zn}$ ). Santa Marta Marina also had high factor loadings for M1, but was better represented by the axis M2. Component M2 had high factor loadings from Santa Marta Marina stations (both with positive factor loadings) and from both Taganga stations (both with negative factor loadings), on both sampling occasions (Oct 2012 and Mar 2013), evidenced by relatively high sediment $\mathrm{Cu}, \mathrm{Hg}, \mathrm{Pb}$ and $\mathrm{Zn}$ and high tissue $\mathrm{Cu}$ and $\mathrm{Sn}$ concentrations in Santa Marta Marina. Component M3 was not representative of any particular station (with low squared cosine values), even though Barú and Ctg-2 (October 2012) had relatively high factor scores, due to elevated sediment As and tissue Cd, whereas the Santa Marta Marina and Taganga had relatively low factor scores. Component M4, represented by sediment Sn, had a high significant negative factor loading only from Ctg-2 (Oct 2012) and positive factor loadings from Barú (Oct 2012).

Using each station's factor scores with respect to the two physical-chemical PCA axes (FQ1 and FQ2) and the four metal PCA axes (M1, M2, M3, M4), a series of step-wise multiple regressions (SWMR) was performed, in order to determine which of the consolidated environmental gradients (represented by the six environmental principal component axes) best explained the observed pattern of the four biomarkers (MT, TChE, Er- ChE and Es- ChE) in digestive gland and gills among the four stations. SWMR results are shown in Table 12. 
Table 12

Step-Wise Multiple Regression (SWMR) for biomarkers vs. environmental gradients represented by six principal components (FQ1, FQ2, M1, M2, M3, M4). Only best model (and overall significance level, p) and best predictor variables shown. Data in bold indicate significant partial regression slopes $(p<0.05)$ of respective predictor variable. Probability for entry: $p<0.15$, probability for removal: $p=0.16$ for all models. For

Er-ChE activity in gills, no significant predictor variables were found.

\begin{tabular}{|c|c|c|c|c|c|c|c|}
\hline $\begin{array}{l}\text { Biomarker } \\
\left(Y_{i}\right)\end{array}$ & Tissue & $\begin{array}{l}\text { Best } \\
\text { Model }\end{array}$ & $\begin{array}{l}\text { Predictor Variables } \\
\left(X_{i}\right) \text { in final model }\end{array}$ & $\begin{array}{l}\text { Standard partial } \\
\text { regression coefficient }\end{array}$ & $\begin{array}{l}\text { p-value for partial } \\
\text { regression coefficient }\end{array}$ & $\begin{array}{l}\text { Adjusted } \\
\mathrm{r}^{2}\end{array}$ & $\begin{array}{l}\text { Overall } \\
\text { Significance } \\
\text { of Model } \\
(\mathrm{Pr}>\mathrm{F})\end{array}$ \\
\hline \multirow[t]{5}{*}{ MT } & \multirow{3}{*}{$\begin{array}{l}\text { Dig. } \\
\text { Gland }\end{array}$} & \multirow{3}{*}{$\begin{array}{l}\mathrm{FQ} 2+ \\
\mathrm{M} 1+\mathrm{M} 2\end{array}$} & FQ2 & 0.75 & 0.003 & 0.47 & \multirow[t]{3}{*}{0.006} \\
\hline & & & M1 & 0.48 & 0.014 & 0.70 & \\
\hline & & & M2 & -0.39 & 0.028 & 0.90 & \\
\hline & \multirow[t]{2}{*}{ Gills } & \multirow[t]{2}{*}{$\mathrm{M} 3+\mathrm{M} 1$} & M3 & 0.83 & 0.001 & 0.64 & \multirow[t]{2}{*}{0.002} \\
\hline & & & M1 & -0.47 & 0.014 & 0.88 & \\
\hline \multirow[t]{4}{*}{ T-ChE } & $\begin{array}{l}\text { Dig. } \\
\text { Gland }\end{array}$ & M3 & M3 & 0.56 & 0.145 & 0.20 & 0.145 \\
\hline & \multirow[t]{3}{*}{ Gills } & \multirow{3}{*}{$\begin{array}{l}\mathrm{M} 1+ \\
\mathrm{FQ} 2+ \\
\mathrm{M} 2\end{array}$} & M1 & 0.61 & 0.037 & 0.27 & \multirow[t]{3}{*}{0.044} \\
\hline & & & FQ2 & 0.56 & 0.047 & 0.59 & \\
\hline & & & M2 & 0.36 & 0.143 & 0.72 & \\
\hline \multirow[t]{2}{*}{ Er- ChE } & $\begin{array}{l}\text { Dig. } \\
\text { Gland }\end{array}$ & M1 & M1 & 0.76 & 0.029 & 0.50 & 0.029 \\
\hline & Gills & $\begin{array}{l}\text { no } \\
\text { variable } \\
\text { found }\end{array}$ & - & - & - & - & - \\
\hline \multirow[t]{4}{*}{ Es- ChE } & $\begin{array}{l}\text { Dig. } \\
\text { Gland }\end{array}$ & M3 & M3 & 0.60 & 0.113 & 0.25 & 0.113 \\
\hline & \multirow[t]{3}{*}{ Gills } & \multirow{3}{*}{$\begin{array}{l}\mathrm{M} 3+\mathrm{M} 1 \\
+\mathrm{FQ} 1\end{array}$} & M3 & 0.45 & 0.007 & 0.18 & \multirow[t]{3}{*}{0.002} \\
\hline & & & M1 & 0.87 & 0.001 & 0.32 & \\
\hline & & & FQ1 & -0.79 & 0.001 & 0.95 & \\
\hline
\end{tabular}

The best consolidated predictor variables for MT in digestive gland were FQ2, M1 and M2 (adjusted $r^{2}=0.90$, overall $p=0.006$ ); whereas for MT in gills, the best components were M3 and M1 (adjusted $r^{2}=0.88$, overall $p=0.002$ ). For the three ChE enzyme fractions, T-ChE activity in digestive gland was best predicted by M3 (adjusted $r^{2}=0.20$, overall $p=0.145$ ), whereas for gills it was the combination of $M 1$, FQ2 and M2 (adjusted $r^{2}=0.72$, overall $p=0.044$ ). For Er-ChE activity in digestive gland, the best model included only M1 (adjusted $r^{2}=0.50, p=0.029$ ). For Es-ChE in digestive gland, the best predictor variable was M3 (adjusted $r^{2}=0.25, p=0.113$ ), whereas it was M3, M1 and FQ1 for Es-ChE in gills (adjusted $r^{2}=0.95, p=0.002$ ). No significant predictor variables were found for Er-ChE activity in gills.

\section{Discussion}

The results of the present study represent the first field measurements of metallothionein-like proteins (MT) and cholinesterase activity (ChE) in oysters from the Colombian Caribbean coast as biomarkers of environmental health. Furthermore, the simultaneous measurement of 22 environmental co-variables (4 physical-chemical water parameters and concentrations of 9 metals in tissue and sediments), at 5 stations along a gradient of approximately $250 \mathrm{~km}$ of coastline, during three time points, permitted the estimation of the relationship between biomarkers (as criterion variables) and environmental co-variables, to identify relevant "predictor" variables and to test the hypothesis that MT concentrations and ChE activity in oyster tissues are sensitive and informative indicators of contaminant exposure and/or effect at the different sampling locations.

This study initially set out to compare environmental contamination patterns and biomarker responses in shellfish along a presumed twodimensional contamination gradient, defined by organophosphates (OP), on the one hand, and metals on the other hand. However, whereas we expected to encounter high pesticide concentrations in Barú (Barbacoas Bay), due to presumed agricultural inputs via the Dique Channel, the sediment and tissue analyses, surprisingly, returned concentrations below detection limits for virtually all organochlorine (OCP = DDTs and 
$\mathrm{HCHs}$ ) and OP compounds, for all five sampling stations (Aguirre-Rubi et al., 2017). Although these pesticide species used to be common contaminants in environmental matrices in the past, their non-detection in the present study is in line with recent national trends indicating a marked recent reduction of pesticide presence in coastal waters of Colombia, with current detection rates of 16\% (Vivas-Aguas et al., 2012; 2015; Garcés-Ordoñez et al., 2016; INVEMAR, 2017). Nevertheless, low tissue concentrations of OPs, whose use is still permitted, might not as much indicate diminished or discontinued use of these pesticides, but rather, low accumulation in tissues and sediments, due to their inherently short environmental half-lives. Lastly, it cannot be ruled out that OCPs and OPs are still present in traces in the coastal environment, but below current limits of detection (which ranged between 2-50 ng/kg for individual compounds).

The results of the metal analyses in oyster tissues (previously reported by Aguirre-Rubi et al., 2017) and in sediments (current study) indicate ubiquity of metal contamination above background at every one of the five sampling stations and underline the disconcerting conclusion that there are no "pristine" (i.e., low metal-concentration) regions in the Colombian Caribbean. The combinations of metals detected at different stations and for sampling dates suggest diverse and variable natural and anthropogenic sources, including industry, domestic discharges, and agriculture (Alonso et al., 2000; Morillo et al., 2004; Fernandez et al., 2007; UNEP; 2008; Olivero-Verbel et al. 2008). The measured sediment concentrations of $\mathrm{As}, \mathrm{Cd}, \mathrm{Cr}, \mathrm{Cu}, \mathrm{Hg}, \mathrm{Ni}, \mathrm{Pb}, \mathrm{Sn}$ and $\mathrm{Zn}$ are consistent with other studies from Colombia and the greater Caribbean that document locally-variable, elevated concentrations of these metals in fluvial, estuarine and coastal sediments, sufficiently high to potentially cause toxic effects in macroinvertebrates and fishes in some cases (Alonso et al., 2000; Vallejo Toro et al., 2016; Barros- Barrios et al., 2016; Tejeda- Benitez et al., 2016; Moncaleano et al., 2017 and 2018, Fernandez-Maestre et al. 2018; Carranza-Lopez et al. 2020). Metals in the present study that had sediment concentrations above the TEL, as defined by Buchman (2008), were As, Cd, Cr, Cu, Hg and Ni.

In contrast to sediments, tissue metal concentrations were typically in the "low" range reported for the sentinel oyster Crassostrea virginica of the US NOAA Mussel Watch Program (MWP, Kimbrough et al., 2008). This was the case for Cu, Pb, Zn (all stations), Sn (exception: Santa Marta Marina Dec 2012 and Mar 2013, and Ctg-2 Oct 2012), As (exception: Taganga Oct 2012), Ni (exception: Taganga-Oct 2012) and Hg (exception: Taganga Oct 2012 and Santa Marta Marina Oct 2012), with noted exceptions having tissue concentrations in the "medium" range. The notable exception was tissue Cd, which exceeded the MWP "high" concentration threshold (15 $\mu \mathrm{g} / \mathrm{g})$ on two occasions (Barú-Oct 2013, Ctg-1-March 2013) and the "medium" threshold on two other occasions (Ctg-1-Dec 2012 and Ctg-2-Oct 2012). Cd tissue concentrations also exceeded the Colombian guideline for human consumption $(1 \mu \mathrm{g} / \mathrm{g})$ of National Resolution 122 of January 26, 2012.

The pattern of apparent metal accumulation in tissues with respect to surrounding sediments is consistent with the biota-sediment accumulation factor (BSAF) profile described for $C$. virginica by Thomann et al. (1995), which tends to decrease in the order: $\mathrm{Zn}>\mathrm{Cd}>\mathrm{Cu}>\mathrm{Hg}$ $>\mathrm{As}>\mathrm{Sn}>\mathrm{Pb}>\mathrm{Cr}>\mathrm{Ni}$, with highest BSAFs (10-100) for $\mathrm{Zn}$ and $\mathrm{Cd}$, intermediate values (BSAF 1-10) for Cu, As and Hg, and lowest BSAF (typically < 1) for $\mathrm{Sn}, \mathrm{Pb}, \mathrm{Cr}$ and $\mathrm{Ni}$. This suggests that the tropical cup oyster species monitored in the present study (Crassostrea rhizophorae and Saccostrea sp.) accumulate metals in much of the same manner as $C$. virginica, indicative of similar physiological mechanisms at play. Nevertheless, in the present study, despite having low apparent BSAF, tissue concentrations of $\mathrm{Sn}, \mathrm{Pb}, \mathrm{Cr}$ and $\mathrm{Ni}$ were found to correlate significantly with sediment metal concentrations, suggesting uptake via sediment-contact, whereas Hg, As and Cd, despite having much higher apparent BSAF values, had rather weak correlations between tissue and sediment concentrations, suggesting uptake via other routes (e.g., food or water). The high Cd tissue concentrations in the present study, compared to reference values, are consistent with laboratory observations, such as those of Géret et al. (2002), that found significant Cd accumulation in Crassostrea gigas after 21 days of exposure in digestive gland $(78 \mu \mathrm{g} / \mathrm{g})$ and gills $(38 \mu \mathrm{g} / \mathrm{g})$, and Moncaleano et al. (2017) who showed rapid and nearly 130-fold Cd accumulation in Saccostrea sp. over a $96 \mathrm{~h}$ exposure period, reaching final tissue concentrations as high as $297 \mu \mathrm{g} / \mathrm{g}$, as well as Gueguen et al. (2017) for Pinctada margaritifera, and Benali et al. (2017) for Mytilus galloprovincialis.

Biomarker and metal concentrations in tissues and sediments showed considerable variation among stations and sampling occasions, precluding the definition of simple and station-specific or date-specific patterns. Moreover, biomarker measurements for a given sampling location were often characterized by high internal variance, evidenced by large standard errors of the mean, resulting in often non-significant differences in ANOVA, despite considerable procedural efforts to reduce measurement variability (e.g., pooling 5 individuals per sample and analyzing triplicate samples). Two-way ANOVA and post hoc analysis (Tukey HSD, $\mathrm{p}<0.05$ ) confirmed significant spatial variance in biomarker responses among the five sampling stations (Santa Marta Marina, Taganga, Ctg-1, Ctg-2 and Barú) for each of the sampling dates (October 2012 and March and October 2013), confirming the absence of a station-specific and temporally-invariant biomarker "profile".

The overall 5-6-fold range of variation of MT concentrations observed in the present study in oyster digestive gland (3.36-15.73 $\mu \mathrm{g} / \mathrm{mg}$ protein) and gills (1.65-9.30 $\mu \mathrm{g} / \mathrm{mg}$ protein) is in line with previously reported MT concentrations for other ostreid species. Moncaleano et al. (2017) reported mean MT concentrations of $8.6 \pm 2.5 \mu \mathrm{g} / \mathrm{mg}$ protein in digestive gland and $9.3 \pm 1.6 \mu \mathrm{g} / \mathrm{mg}$ protein in gills of field-collected Saccostrea sp. exposed to seawater in the laboratory for $96 \mathrm{~h}$ (= controls). Likewise, Gold-Bouchot et al. (2007) reported MT concentrations ranging between $4-32 \mu \mathrm{g} / \mathrm{mg}$ in digestive gland and gills of $C$. virginica collected in the Laguna de Terminos, Mexico; and Bernal- Hernandez et al. 2010 reported MT concentrations in gills between $2.1-21.3 \mu \mathrm{g} / \mathrm{mg}$ in Crassostrea corteziensis from the Boca de Camichín estuary in 
Mexico. The higher MT concentrations in digestive gland compared to gills are consistent with previous studies (Amiard et al., 2006; Jenny et al., 2004; Moncaleano et al., 2017).

The enzyme activities of the three different cholinesterase fractions analyzed, T-ChE (digestive gland: 15.1-49.1; gills: 14.5-69.1 $\mathrm{nmol} / \mathrm{min} / \mathrm{mg}$ protein), Es-ChE (digestive gland 6.2-58.6; gills 4.3-40 nmol/min/mg protein) and Er-ChE (digestive gland 3.6-19.4; gills 6.6$46.8 \mathrm{nmol} / \mathrm{min} / \mathrm{mg}$ protein), were very variable and somewhat higher when compared to the range reported by Moncaleano et al. (2018) for field-collected Saccostrea sp., exposed to seawater (= controls) in the laboratory for $96 \mathrm{~h}$ (T-ChE in digestive gland: 5.2-28.1 and gills: 9.316.4; Es-ChE in digestive gland: 3.5-16.9 and gills: 2.3-11.5; Er-ChE in digestive gland: 5.5-19.5 and gills: 5.4-12; activity expressed in $\mathrm{nmol} / \mathrm{min} / \mathrm{mg}$ protein). Similar ChE activities have also been observed for several other bivalve species, with Bocquene et al. (1997) reporting ChE activity of $28.1 \pm 2.8 \mathrm{nmol} / \mathrm{min} / \mathrm{mg}$ protein in gills of $C$. gigas; Mora et al. (1999) reporting $25.3 \pm 7.7 \mathrm{nmol} / \mathrm{min} / \mathrm{mg} \mathrm{protein}$ in gills of $M$. galloprovincialis activities; Valbonesi et al. (2013) reporting $5.8 \pm 1.9 \mathrm{nmol} / \mathrm{min} / \mathrm{mg}$ protein ChE in gills of Ostrea edulis and $16.7 \pm 4.8$ $\mathrm{nmol} / \mathrm{min} / \mathrm{mg}$ protein in gills of $M$. galloprovincialis; Peric et al. (2013) reporting activities less than $10 \mathrm{nmol} / \mathrm{min} / \mathrm{mg} \mathrm{protein}$ in gills of Arca noae, and Bautista- Covarrubias et al. (2017) reporting $0.4-2.5 \mathrm{nmol} / \mathrm{min} / \mathrm{mg}$ protein in gills of Crassostrea sp. during dry season and $8.3-$ $34.4 \mathrm{nmol} / \mathrm{min} / \mathrm{mg}$ protein during rainy season.

None of the four biomarkers measured displayed evidence of marked induction (in the case of MT) or marked inhibition (in the case of ChE activity) at any station, with values generally varying by less than a factor of 5 among stations or sampling occasions. This might be the consequence of an inherently low dynamic range of these biomarkers, reflecting tight metabolic control by oysters, or might be due to the fact that contaminant concentrations in sediments and tissues were generally non-detectable (for OPs) or below toxicological thresholds (for the majority of metals) likely to cause significant up- or down-regulation of these biomarkers, which often tend to be 10 times higher in laboratory exposures (Mourgaud et al. 2002; Moncaleano et al., 2017 and 2018).

Water parameters (temperature, salinity, dissolved oxygen, and pH) and the 9 metal species, analyzed in tissues and sediments, showed a complex, multi-dimensional concentration pattern among the five sampling stations. To reduce the number of environmental variables and to test the hypothesis that tissue biomarker correlated with broader contamination gradients, two separate PCAs were applied to distinguish the variance contribution of contaminant co-variables from physical-chemical co-variables, resulting in a total of six principal environmental components. Two distinct physical-chemical gradients were identified, represented by two principal component axes, named FQ1 (correlating with salinity and dissolved oxygen), and FQ2 (correlating with $\mathrm{pH}$ and temperature). These two main components were found to summarize in a more holistic way the hydrographic environmental gradients experienced by oysters at the sampling stations (rather than the four individual variables temperature, salinity, dissolved oxygen, and $\mathrm{pH}$ by themselves), bearing in mind that oysters are exposed to more than one environmental variable at the same time.

In the case of the metals, four compositionally distinct gradients were identified by PCA, one (M1) whose composition resembled an "urban/industrial"-type contamination profile (defined by tissue $\mathrm{Hg}, \mathrm{Ni}, \mathrm{Pb}$ and $\mathrm{Zn}$ and sediment $\mathrm{Cd}$, $\mathrm{Cr}$ and $\mathrm{Ni}$ ), typical of Taganga Bay on one extreme, which receives input from an underwater sewer outfall from Santa Marta, a second one (M2) suggestive of maritime antifouling paint inputs (high tissue Cu, Sn), as exemplified by Santa Marta Marina), a third one (M3) characterized by likely riverine and agricultural inputs (high tissue $\mathrm{Cd}$ and sediment As), characteristic of the three Cartagena/ Barbacoas Bay stations (Barú, Ctg-1 and Ctg-2), all in the proximity of the Dique Channel, and a fourth (M4), represented by elevated sediment Sn concentrations, for which Barú, Taganga and Santa Marta Marina (October 2012) had substantial associations.

Stepwise multiple regression between the biomarkers and the 6 PCA components confirmed significant correlations, between some of the biomarkers and the two physical-chemical parameter gradients: For example, MT in digestive gland and T-ChE activity in gills correlated significantly with FQ2 (and individually with pH and temperature), whereas Es-ChE activity in gills correlated significantly with FQ1 (and individually with salinity and DO). On the other hand, MT in gills and T-ChE and Es-Che activity in digestive gland did not correlate significantly with any of the two principal FQs, nor did Es-ChE activity in either of the tissues, even though they showed weak correlations with individual water parameters (e.g., MT in gills with temperature, $\mathrm{pH}$ and DO). The observed correlations between MT and ChEs with physicalchemical variables (or the consolidated gradient axes) are plausible and consistent with other field studies that have shown these two biomarkers to be modulated significantly due to seasonal, oceanographic (i.e. temperature and salinity), nutritional and reproductive variation (Escartin and Porte, 1997; Doran et al., 2001; Choi et al., 2011, Leiniö and Lehtonen, 2005), explaining why the amplitude of biomarker responses in field studies generally tends to be greater than in controlled laboratory studies.

An important finding of this study was that next to the physical-chemical parameters, tissue biomarkers also correlated significantly with three of the four metal component axes, with best predictor variables varying depending on biomarker: In the case of MT in digestive gland, the best contaminant predictor variables were principal components M1 and M2, whereas for MT in gills, they were M3 and M1. For the three ChE enzyme fractions, the most frequent predictor variable was M1 (for T-ChE gills, and Es-ChE in digestive gland and gills), followed by M3 (for T-ChE digestive gland, Es-ChE gills), with only one significant correlation found with component M2 (T-ChE in gills). No significant

Page 17/32 
environmental predictor variables were found for Er-ChE activity in gills. Conversely, principal component M4 had no significant correlation with any of the biomarkers studied. Recalling that principal component M1 had strong loadings from sediment $\mathrm{Cd}$, $\mathrm{Cr}$ and $\mathrm{Ni}$, as well as from tissue $\mathrm{Hg}, \mathrm{Ni}, \mathrm{Pb}$ and $\mathrm{Zn}$, it appears that these proxies of urban-contamination are responsible for the modulation of five of the eight biomarkers (MT-dg, MT-gi, T-ChE-gi, Es-Che-dg and Es-ChE-dg, with dg denoting "digestive gland" and gi "gill", respectively). Environmental component $\mathrm{M} 2$, represented by a gradient of sediment $\mathrm{Cu}, \mathrm{Hg}, \mathrm{Pb}$ and $\mathrm{Zn}$ and elevated tissue $\mathrm{Cu}$ and $\mathrm{Sn}$ concentration, best exemplified by Santa Marta Marina (and inversely, by Taganga station), was a significant predictor for only two biomarkers (MT-dg and T-ChE-gi). Lastly, component M3, indicative of elevated sediment As and tissue Cd, was a significant predictor of three biomarkers (MT-gi, T-ChE-dg and Es-ChEgi), which were elevated in Barú and Ctg-2. The results of the SWMR using the consolidated environmental gradients (summarized in Table 12), thus, clearly show that MT and ChE biomarkers are modulated by a combination of physical-chemical and metal variables, of which the metal gradients more frequently were selected as significant predictor variables in SWMR (absolute frequency of inclusion in best model: 10) compared to the physical-chemical gradients (absolute frequency of inclusion in best model: 3 ).

More specific analyses of the relationships between biomarkers and individual environmental variables using SWMR and Spearman correlation helped to identify significant individual environmental variables that might be directly (i.e., mechanistically) or indirectly (i.e., as proxies of direct causes) involved in modulating the different biomarker responses. In the majority of SWMR models, positive correlations were observed between biomarkers and metal variables, with tissue metals more frequently displaying positive partial regression coefficients (12 positive vs. 5 negative significant standard partial regression coefficients, Table 11) than sediment metals (7 positive vs. 5 negative regression coefficients). Combining the results of SWMR-A and B, the sum of positive significant partial regression coefficients was: 19 positives vs. 10 negatives, indicating a marked prevalence of positive correlations between biomarkers and metal concentrations. In contrast, physical-chemical co-variables showed no preferred correlation pattern with biomarkers, with 7 positive and 7 negative regression coefficients for the totality of SWMR models examined.

The current finding of apparent induction of MT in gills by Cd is consistent with results from controlled laboratory studies, such as Viarengo et al. (1989) in M. galloprovincialis, who showed upregulation of MT in gills after 2 days of exposure to Cd. Similarly, Roesijadi et al. (1997) demonstrated significantly increased expression of MT in $C$. virginica after 2 days of Cd exposure (at 73-fold ambient concentrations), as did Géret et al. (2002) in C. gigas after Cd exposure (200 $\mu \mathrm{g} / \mathrm{L})$ over 21 days. Likewise, Jenny et al. (2004) observed significant upregulation of MT gene transcription in gills and digestive glands of $C$. virginica exposed for $96 \mathrm{~h}$ to $\mathrm{Cd}$ (0.25-0.44 M, approx. 28-50 g/L), similar to Aceto et al. (2011), who reported increased gene expression (MT-10, MT-10 Intronless, MT-20) in field-exposed M. galloprovincialis. Finally, Yingprasertchai et al (2019) also reported an increased expression of sgMT due to Cd stress at $200 \mu \mathrm{g} / \mathrm{L}$ in the Sydney rock oyster Saccostrea glomerata. Moncaleano et al. (2017) also observed up to two-fold increase of the MT concentrations in digestive gland and gills of Saccostrea sp. exposed to $\mathrm{Cd}(100 \mu \mathrm{g} / \mathrm{L}, 96 \mathrm{~h})$; Gueguen et al. (2017) reported significant up-regulation of MT by Cd in Pinctada margaritifera, noting furthermore that Cd stimulated significant changes in the transcription of individual genes and Chan \& Wang (2019) reported elevated MT concentrations (20-70 $\mu \mathrm{g} / \mathrm{g}$ wet wt.) in Crassostrea hongkongensis, related with a strongly detoxification response for Cd in whole oyster tissues. Nevertheless, the Cd concentrations measured in whole tissues in the present study $(0.73-22.86 \mu \mathrm{g} / \mathrm{g}) \mathrm{were}$ considerably below those reported by previous authors to acutely induce MTs (e.g. Moncaleano et al. 2017 found that MT concentrations in digestive gland and gills of Saccostrea sp. were invariant to acute Cd exposure $<100 \mu \mathrm{g} / \mathrm{L}$ over $96 \mathrm{~h}$, corresponding to Cd whole-tissue concentrations of $30 \mu \mathrm{g} / \mathrm{g}$ ), suggesting that $\mathrm{Cd}$ exposure in the field was not quite high enough to produce marked site-specific differences in MT levels.

The apparent induction of MT in digestive gland by Ni is supported by observations by Mourgaud et al. (2002), who demonstrated that Ni induces MT in M. galloprovincialis (as well as Cd, Cu, and Zn) and is also able to bind to MT proteins. Similarly, Attig et al. (2010) reported a significant increase of MT in digestive gland of $M$. galloprovincialis exposed to Ni at $2.5 \mu \mathrm{M}$ and $13 \mu \mathrm{M}$, consistent with Costa et al. (1994) who noted high affinity of Ni for sulfhydryl groups of proteins, including MTs. Peric et al. (2012) also reported a strongly positive, albeit statistically non-significant correlation, between MT content and tissue Ni concentrations in M. galloprovincialis (Ni concentrations between 0.47 to $2.78 \mathrm{mg} / \mathrm{kg}$ ). MT induction by Ni has been reported not only in bivalves but also in the cod Eleginus nawaga (Eriksen et al., 1990) and in the copepod Tigriopus brevicornis (Barka et al. 2001). On the other hand, Amiard et al. (2008) did not find correlation between MT and Ni concentrations in mussels exposed to $\mathrm{Ni}$ in field and laboratory conditions. For Zn, Peric et al. (2012) reported a positive correlation between MT content and tissue $\mathrm{Zn}$ in M. galloprovincialis (Zn concentration 117-271 mg/kg). Nevertheless, other authors failed to observe increases of tissue MT concentrations by Zn and Cu exposure (Géret et al., 2002; Jenny et al., 2004; Amiard et al.2008; Moncaleano et al, 2017). Interestingly, Liu and Wang (2016) reported a significant negative relationship between $\mathrm{Cu}, \mathrm{Zn}, \mathrm{Cr}$ and Ni with MT concentration for $C$. hongkongensis and Crassostrea angulata, a finding also reported for Crassostrea sikamea by Weng and Wang (2014) after Cu and Zn exposure. This situation shows that there is still a lack of consensus regarding the effects of metals on metal regulation in bivalve species. Undoubtedly, protein regulation responses vary among species, due to differences in metal sequestration mechanisms, such as scavenging by metallothionein and other metal complexes or differences in metallothionein turnover rates that are still unknown and metals (Wang and Rainbow, 2010). 
MT induction by As has been observed in Corbicula fluminea for aqueous As concentrations as low as $100 \mu \mathrm{g} / \mathrm{L}$ (Santos et al. 2007), corroborating the strong correlations observed between As and MT in gills in the present study. For Hg, Géret et al. (2002) reported induction of MT in gills in C. gigas, corresponding to $\mathrm{Hg}$ tissue concentrations of $22.6 \pm 3.9 \mu \mathrm{g} / \mathrm{g}$ in digestive gland and $74.8 \pm 14 \mu \mathrm{g} / \mathrm{g}$ in gills, which is very high compared with the tissue concentration of $\mathrm{Hg}$ in the present study $(<0.18 \mu \mathrm{g} / \mathrm{g})$. Nevertheless, Mourgaud et al. (2002) reported that $\mathrm{Hg}$ was not a significant inducer of MT in M. galloprovincialis and neither was As, $\mathrm{Cr}$ and Pb. On the other hand, Gueguen et al. (2017) reported significantly up-regulated expression of $\mathrm{MT}$ in in $P$. margaritifera upon $\mathrm{Cr}$ exposure concentrations between $1-10 \mu \mathrm{g} / \mathrm{L}$, even though $\mathrm{Cr}$ accumulation was low, with $\mathrm{Cr}$ tissue concentrations $<10 \mu \mathrm{g} / \mathrm{g}$ dry weight, which is comparable to the $\mathrm{Cr}$ concentrations in the present study $(0.23-9.14 \mu \mathrm{g} / \mathrm{g})$. Despite Cr not being selected in the SWMR models as a significant predictor variable of MT, single Pearson correlations between MT and Cr did show significant correlations. However, due to the strong covariance between $\mathrm{Cr}$ and $\mathrm{Ni}$, SWMR models favored the inclusion of $\mathrm{Ni}$ over $\mathrm{Cr}$, due to a higher partial regression coefficient.

Finally, some authors have shown that variation in MT content is not due exclusively to metal concentrations but related to other environmental and biological factors as well. For example, Geffard et al. (2001) reported that MT levels in digestive glands of $C$. virginica in the Gironde estuary (France) were strongly affected by seasonal variations and body size, while Raspor et al. (2004) observed that variations in MT content of M. galloprovincialis (digestive gland) were partially explained by inherent biological co-variables, such as sexual maturation, gland size and food availability. Similarly, Leiniö and Lehtonen (2005) observed significant seasonal variations in MT content in Mytilus edulis and Macoma balthica, whereas Amiard et al. (2006) noted a low correlation between MT concentrations and environmental metal concentrations in aquatic invertebrates, which they attributed to differential responses of different isoforms of MT.

Ivanina et al. (2009) reported a significant temperature effect on MT expression in C. virginica, whereas Riba et al. (2003) observed an inverse effect of $\mathrm{pH}$ and salinity on the uptake of $\mathrm{Zn}$ and on MT concentrations in Ruditapes philippinarum. Other studies, likewise, have reported considerable negative correlation between salinity and MT levels in the digestive gland of mussels M. galloprovincialis (Ivanković et al 2005; Hamer et al. 2008, Sun et al. 2018). Considering these results, it, therefore, comes as no surprise that temporal and spatial differences in MT concentrations in the present study, as confirmed by ANOVA, were partially explained by environmental co-variables, such as pH (MT-dg and MT-gi) and temperature (MT-gills) in the SWMR, consistent with high regression coefficients of the consolidated principal component FQ2 (carrying strong factor loadings from $\mathrm{pH}$ and temperature).

The failure to observe pronounced inhibition of ChE activity at any of the locations in the present study is consistent with the overall finding of non-detectable OP concentrations in sediments and oyster tissues. Whereas ChE activity can be modulated by subtle differences OP and carbamate exposure concentrations (Montserrat et al., 2002, 2007, Bernal- Hernandez et al., 2010), the consistent failure off detecting OPs in sediments and tissue argues against using variations in OP concentrations to explain the spatial and temporal variations in the activity of the three cholinesterases observed, and, instead, suggests influences of other environmental and/or biological variables. Next to OPs and carbamates, ChE activity is known to be affected by a variety of metals, as well as PAHs, hydrocarbons, detergents, phytotoxins and other classes of pesticides such as neonicotinoids (Magni et al. 2006; Senger et al. 2006; Choi et al. 2011; Moncaleano et al., 2018), only a fraction of which were measured in in the present study. In this respect, it is peculiar that enzyme activity of the three kinds of ChEs tended to correlate positively with many the analyzed metal species in sediments ( $\mathrm{Cr}, \mathrm{Cd}, \mathrm{Cu}, \mathrm{Ni}$ and $\mathrm{Sn}$ ) and tissues (As, $\mathrm{Cd}, \mathrm{Cr}, \mathrm{Hg}, \mathrm{Pb}, \mathrm{Sn}, \mathrm{and} \mathrm{Zn}$ ). We conjecture that the generally positive correlation between ChE activity and metal concentrations might be due to a stimulatory effect of metals on ChE expression of oysters, perhaps by a global up-regulation of stress responses, resulting in increased production of ChE protein (among others), even though each enzyme molecule by itself might be susceptible to kinetic inhibition by metals. Since sediment metal concentrations (and therefore water concentrations) were generally low (i.e., below TEL for most metals), exposure concentrations might simply not have been high enough to elicit kinetic inhibition of ChEs. Therefore, it is quite possible that oysters with elevated ChE activities were "up-regulating" ChE protein concentrations, as part of a non-specific stress response to metals and other, unmeasured, environmental contaminants. Interestingly, the few metal species whose tissue concentrations did correlate negatively with ChE activity, namely As (standard partial regression coefficient $r_{s}=-0.69$ and -0.83 , for Er-ChE-dg and Er-ChE-gi), Cd $\left(r_{s}=-0.23\right.$, for Es-ChE-dg) and Sn ( $r_{s}=-0.11$, for Es-ChE-dg) were those for which tissue concentrations exceeded the "medium" or "high" thresholds relative to MWP reference values, as was characteristic of oysters from Barú and Ctg-2, where tissue $\mathrm{Cd}$ and tissue As were high but ChE activity low. An inhibitory effect of Cd on cholinesterases has been confirmed for various bivalve species, including M. galloprovincialis (Magni et al. 2006, Tsangaris et al., 2010), Adamussium colbecki (Bonacci et al., 2006, Cravo et al., 2012), Ruditapes decussatus (Cravo et al. 2012), Meretrix casta (D'Costa et al. 2017) and Saccostrea sp. (Moncaleano et al., 2018), supporting the possibility that oysters with elevated tissue Cd and relatively low ChE activities, as was the case for oysters from Barú and Ctg-2, might have been inhibited by Cd. Regarding As, laboratory studies have shown both significant inhibition of ChE activity by As in the freshwater clam Lamellidens marginalis (Chakraborty et al., 2012), as well as induction of ChE expression by As in Perna indica (Rajkumar et al. 2013). Negative correlations between ChE activity and Cu and Cr (as observed in C. virginica by Gold Bouchot et al., 2007) and Ni in M. galloprovincialis (Attig et al., 2010) are not corroborated by our field results. 
Next to metals, variations in ChE activity in gills were also partially explained by physical-chemical variables (salinity, temperature, and pH) with negative correlations prevailing over positive regressions in SWMR models (6 negative regression coefficients vs. 2 positive regression coefficients). Among the four physical-chemical variables, salinity returned strongly negative partial regression coefficients $\left(r_{s}<-0.5\right.$, with $T-$

ChE-dg, Es-ChE-dg and Es-ChE-gi) whereas temperature showed predominantly positive regression coefficients ( $r_{s}>0.5$, with T-ChE-gi and EsChE-gi), whereas regression coefficients for $\mathrm{pH}$ as a predictor of ChE activity where negligible $\left(r_{\mathrm{s}}=-0.008\right.$, with Es-ChE-dg).

The three-way ANOVA showed that next to spatial and temporal effects (due to spatial- temporal variations in environmental predictor variables), the concentration of MT and the activity of the three different types of cholinesterases (T-ChE, Es-ChE and Er-ChE) were also influenced by the type of tissue (digestive gland or gills). This biological source of variability is well-known, and Lowe \& Day (2002), GoldBouchot et al. (2007), Bernal- Hernandez et al. (2010) and Andrade-Brito (2012) have all recommended gills as the most suitable tissue for the measurement of biomarkers, first because gills represent the largest surface area in contact between the individual and the environmental, and second, because gill tissues are highly permeable, which favors rapid uptake of waterborne contaminants, as the filter-feeding process not only retains food, but also a wide variety of other particulate and dissolved substances, including metals and pesticides. For MT, the use of the gill as well as digestive gland is common, since next to being sensitive to MT exposure they also tend to display highest MT concentrations (Bebianno et al., 1993; Mackay et al., 1993; Baudrimont et al., 1997; Mouneyrac et al., 1998; Geffard et al., 2001; Ceratto et al., 2002), compared to other tissues, such as muscle. For cholinesterases, previous studies have reported high activity and sensitivity in the gill, mantle, and adductor muscle (Monserrat et al., 2002; Damiens et al., 2004; Bernal-Hernández et al., 2010), yet also in digestive gland (Bocchetti et al., 2008; Moncaleano et al. 2018). The sensitivity of MT and ChE activity in both gill and digestive gland tissue, as observed in the present study, shows that both tissues are suitable for the measurement of these biomarkers in future monitoring programs in Colombia, even though each tissue responds in a different manner to environmental variables.

This study demonstrated that MT and ChE activity in cup oysters varied significantly between stations and sampling dates, which was explained to a large extent by variations in environmental parameters, including physical-chemical water variables (T, S, pH and DO) and sediment and tissue metal concentrations, which differed among stations and sampling dates. The consolidation and re-partitioning of environmental co-variables, from 22 dimensions (i.e., 4 physical-chemical water parameters, 9 tissue metals and 9 sediment metals) to only 6 main components greatly helped in data reduction and for defining major orthogonal environmental gradients and for estimating relative weight of each. The integrated analysis (excluding Ctg-1 station, due to data deficiency and untypically high ChE activities), showed that MT and cholinesterase biomarkers responded differentially to the principal environmental gradients, indicating non-redundancy of the two biomarkers. The inclusion of metal gradients as significant explanatory variables in stepwise multiple regression models for all but one of the 7 biomarkers variables, highlights their probable mechanistic involvement in modulating the observed biomarker responses. Nevertheless, bearing in mind that the environmental gradients were derived from two separate PCAs, it is entirely possible that the 2 physical-chemical gradients (FQ1 and FQ2) and the 4 metal gradients (M1, M2, M3, M4) were not strictly orthogonal (i.e., statistically independent), but interrelated, resulting in the favoring of one over the other in the SWMR models, even though both might be part of the same gradient.

\section{Conclusions}

The present study produced no evidence of current organophosphate contamination and cholinesterase activity inhibition in tropical cup oysters and coastal sediments at five monitoring stations along the Colombian Coast. In contrast, metal contamination was found to be ubiquitous, with different and spatial-temporally complex concentration patterns in sediments and oyster tissues at different sampling sites and sampling occasions, indicative of compositionally and temporally variable metal exposure. Three compositionally distinct contamination gradients were defined using PCA: (1) an "urban/industrial"-type, defined by Hg, Pb, Cr, Ni and Zn (typical of Taganga Bay), (2) one suggestive of maritime antifouling paint inputs (e.g., Cu, Sn, as exemplified by Santa Marta Marina) and (3) a contamination type characterized by likely riverine and agricultural contamination inputs (Cd and As), characteristic of the three Cartagena/ Barbacoas stations (Barú, Ctg-1 and Ctg-2), all of which lie in the proximity of the Canal de Dique, which drains extensive agricultural areas. For most metals studied, concentrations in sediments were below probable effects levels (PEL) and, therefore, unlikely to cause significant adverse effects in resident biota. In line with this, metal concentrations in whole oyster tissue tended to be low to moderate for most metals analyzed, except for Cd, which exceeded the Mussel Watch Program "high" level in two locations (Barú and Ctg-1). Metallothionein-like proteins and the three operationally defined cholinesterase activity fractions measured in oyster digestive gland and gills varied by a factor of 5-6 among the five monitoring stations, with average biomarker values correlating positively (yet distinctly for each biomarker) with the three metal contamination gradients. Nevertheless, neither contamination profiles in sediment and oyster tissues, nor biomarker patterns were station-specific, displaying high temporal variability between sampling occasions, suggesting high spatial-temporal variability in contamination inputs or influences by other environmental co-variables. Consistent with the generally low to moderate metal concentrations in sediments and bivalve tissues, levels of the four protein biomarkers studied (MT, T- ChE, Es-ChE and Er- ChE), were inconspicuous and comparable (within a factor of 5) to baseline values reported for other bivalve species, showing little evidence of substantial induction (in the case of MT) or inhibition (in the case of ChE

Page 20/32 
activity). This suggests that the general contamination status of oysters taken from two principal urban coastal areas along the Colombian Caribbean (Cartagena and Santa Marta) is within baseline ranges of other bivalve species. Nevertheless, although varying only moderately in amplitude, biomarker levels did show statistically significant variations among sites and sampling occasions, with differences in biomarker levels correlating in a predominantly positive manner with differences in metal concentrations and physical-chemical conditions, indicative of sub-lethal biochemical effects. This suggests that oysters are indeed responding, albeit within a moderate and narrow amplitude, to differences in metal and physical-chemical exposure in their surroundings. The correlation of different biomarkers with different contamination gradients (identified by principal component analysis) as well as natural physical-chemical gradients shows that the studied biomarkers are susceptible to modulation by both kinds of environmental factors. Notably, higher MT concentrations in digestive gland and gills correlated with elevated tissue $\mathrm{Ni}$ and $\mathrm{Cd}$ concentrations (as well as higher pH), whereas T-ChE and Es-ChE activity correlated positively with tissue $\mathrm{Pb}$ and $\mathrm{Zn}$ (as well as salinity and temperature, in the case of T-ChE activity). On the other hand, Er-ChE activity correlated positively with tissue $\mathrm{Hg}$ and $\mathrm{Cr}$ concentrations (as well as temperature), underscoring the sensitivity of the different individual biomarkers to different environmental variables, and highlighting the fact that biomarker responses are heterogeneous and distinct. As a general trend, MT and ChE activity tended to correlate positively with tissue metal concentrations, indicative of a tendency towards up-regulation of these biomarkers by metals. While this is to be expected for MTs, the positive correlation (rather than inhibition) between ChE activity and tissue metals is surprising and currently unexplained. Whereas the lack of clear ChE inhibition in oysters is consistent with non-detectable OP concentrations in oyster tissues and sediments, the positive correlations of ChE activity with some metals support the conclusion that ChEs, rather than being specific biomarkers of organophosphate and carbamate exposure, may in fact, be inducible by metals (or correlate positively with other non-metal covariables). This apparent sensitivity of ChE activity to metal exposure seems to make cholinesterases more general indicators of contaminant exposure and suggests their re-consideration in environmental monitoring programs in a broader way.

\section{Declarations}

\section{Ethics approval and consent to participate}

Not applicable

\section{Consent for publication}

Not applicable

\section{Data availability statements}

The datasets used and/or analyzed during the current study are available from the corresponding author on reasonable request.

\section{Competing interests}

All authors declare that they have no competing financial interests.

\section{Contribution Statement}

AMMN: Conceptualization, Methodology, Formal analysis, Investigation, Writing-Original Draft, Visualization. MMCC: Methodology, Formal analysis, Writing-Review \& Editing. ALA: Conceptualization, Methodology, Writing-Review \& Editing, Funding acquisition. LV: Conceptualization, Methodology, Writing-Review \& Editing. SCR: Methodology. MJA: Conceptualization, Review \& Editing, Project administration, Funding acquisition. All authors read and approved the final manuscript.

\section{Acknowledgments}

We thank I. Marigómez, J. Aguirre- Rubi, N. Etxebarria, M. Soto and colleagues from the Research Centre for Experimental Marine Biology and Biotechnology (Plentzia Marine Station; PiE-UPV/EHU), University of Basque Country, for performing metal analysis in oyster tissues. We, furthermore, thank L. Espinoza (Invemar, Santa Marta) for pesticide analysis and the municipal marina of Santa Marta for authorizing access to their facilities. This study was carried out in accordance with decree 1376-2013 by the Colombian Ministry for the Environment and Sustainable Development (MADS) under a general collection permit issued to Jorge Tadeo Lozano University by the Colombian National Authority for Environmental Licenses (ANLA, Res.1271-2014).

\section{Funding}

Financial support for this study came in part from a research grant from the SPANISH AGENCY FOR INTERNATIONAL DEVELOPMENT COOPERATION (CARIBIOPOL-AECID 11-CAP2-1595), as well as from a research grant from JORGE TADEO LOZANO UNIVERSITY (research 
grant 560-10-13, project MOSAICO-I) and from a scholarship to A.M. from COLCIENCIAS (Announcement No. 528).

\section{References}

1. Aceto S, Formisano G, Carella F, De Vico G, Gaudio L (2011) The metallothionein genes of Mytilus galloprovincialis: genomic organization, tissue expression and evolution. Marine Genomics 4:61-68

2. Aguirre- Rubi JR, Luna- Acosta A, Etxebarría N, Soto M, Espinoza F, Ahrens MJ, Marigómez I (2017) Chemical contamination assessment in mangrove-lined Caribbean coastal systems using the oyster Crassostrea rhizophorae as biomonitor species. Environ Sci Pollut Res 25(14):13396-13415

3. Aguirre-Rubi JR, Luna-Acosta A, Ortiz-Zarragoitia M, Zaldibar, Izagirre U, Ahrens MJ, Villamil L, Marigómez I (2018) Assessment of ecosystem health disturbance in mangrove-lined Caribbean coastal systems using the oyster Crassostrea rhizophorae as sentinel species. Science of the Total Environment 618:718-735

4. Alonso D, Pineda P, Olivero J, Gonzalez H, Campos N (2000) Mercury levels in muscle of two fish species and sediments from the Cartagena Bay and the Ciénaga Grande de Santa Marta, Colombia. Environ Pollut 109:157-163

5. Al-Subiai SN, Moody AJ, Mustafa SA, Jha AN (2011) A multiple biomarker approach to investigate the effects of copper on the marine bivalve mollusc, Mytilus edulis. Ecotoxicol Environ Saf 74:1913-1920

6. Amiard JC, Amiard-Triquet C, Barka S, Pellerin J, Rainbow PS (2006) Metallothioneins in aquatic invertebrates: their role in metal detoxification and their use as biomarkers. Aquat Toxicol 76:160-202

7. Amiard JC, Journel R, Bacheley H (2008) Influence of field and experimental exposure of mussels (Mytilus sp.) to nickel and vanadium on metallothionein concentration. Comparative Biochemistry Physiology C 147:378-385

8. Andrade- Brito I, Freire CA, Yamamoto FY, De Assis HCS, Souza-Bastos LR, Cestari MM, De Castilhos Ghisi N, Prodocimo V, Neto F, Oliveira Ribeiro F, C.A (2012) Monitoring water quality in reservoirs for human supply through multi-biomarker evaluation in tropical fish. J Environ Monit 14:615-625

9. Attig H, Dagnino A, Negri A, Jebali J, Boussetta H, Viarengo A, Dondero F, Banni M (2010) Uptake and biochemical responses of mussels Mytilus galloprovincialis exposed to sublethal nickel concentrations. Ecotoxicol Environ Saf 73:1712-1719

10. Barata C, Solayan A, Porte C (2004) Role of B-esterases in assessing toxicity of organophosphorus (chlorpyrifos, malathion) and carbamate (carbofuran) pesticides to Daphnia magna. Aquat Toxicol 66:125-139

11. Barka S, Pavillon JF, Amiard JC (2001) Influence of different essential and non-essential metals on MTLP levels in the Copepod Tigriopus brevicornis. Comparative Biochemistry Physiology C 128:479-493

12. Barros- Barrios O, Doria- Argumedo C, Marrugo- Negrete J (2016) Metales pesados ( $\mathrm{Pb}, \mathrm{Cd}, \mathrm{Ni}, \mathrm{Zn}, \mathrm{Hg}$ ) en tejidos de Lutjanus synagris y Lutjanus vivanus de la Costa de La Guajira, Norte de Colombia. Veterinaria y Zootecnia 10 (2), 27-41

13. Baudrimont M, Metivaud J, Maury-Brachet R, Ribeyre F, Boudou A (1997) Bioaccumulation and metallothionein response in the Asiatic clam (Corbicula fluminea) after experimental exposure to cadmium and inorganic mercury. Environ Toxicol Chem 16:2096-2106

14. Bautista- Covarrubias JC, Villaseñor M, Bueno A, Gutierrez D, Voltolina D, Frías-Espericueta MG (2017) Cholinesterase activity in Crassostrea sp. of Nayarit (NW MEXICO) Coastal waters. Revista Internacional de Contaminación Ambiental 33(2):215-220

15. Bebianno MJ, Barreira LA (2009) Polycyclic aromatic hydrocarbons concentrations and biomarker responses in the clam Ruditapes decussatus transplanted in the Ria Formosa lagoon. Ecotoxicol Environ Saf 72:1849-1860

16. Bebianno MJ, Nott JA, Langston WJ (1993) Cadmium metabolism in the clam Ruditapes decussata: the role of metallothioneins. Aquat Toxicol 27:315-334

17. Benali I, Boutiba Z, Grandjean D, De Alencastro LF, Rouane-Hacene O, Chèvre N (2017) Spatial distribution and biological effects of trace metals ( $\mathrm{Cu}, \mathrm{Zn}, \mathrm{Pb}, \mathrm{Cd})$ and organic micropollutants (PCBs, PAHs) in mussels Mytilus galloprovincialis along the Algerian west coast. Mar Pollut Bull 115:539-550

18. Bernal-Hernández YY, Medina-Díaz IM, Robledo-Marenco ML, Velázquez-Fernández JB, Girón-Pérez MI, Ortega-Cervantes L, MaldonadoVázquez WA, Rojas-García AE (2010) Acetylcholinesterase and metallothionein in oysters (Crassostrea corteziensis) from a subtropical Mexican Pacific estuary. Ecotoxicology 19:819-825

19. Bocchetti R, Lamberti CV, Pisanelli B, Razzetti EM, Maggi C, Catalano B, Sesta G, Martuccio G, Gabellini M, Regoli F (2008) Seasonal variations of exposure biomarkers, oxidative stress responses and cell damage in the clams, Tapes philippinarum, and mussels, Mytilus galloprovincialis, from Adriatic Sea. Marine Environmental Research 66:24-26

20. Bocquene G, Roig A, Fournier D (1997) Cholinesterases from the common oyster (Crassostrea gigas) evidence for the presence of a soluble acetylcholinesterase insensitive to organophosphate and carbamate inhibitors. FEBS Lett 407:261-266 
21. Bonacci S, Corsi I, Focard S (2006) Cholinesterases in the Antarctic scallop Adamussium colbecki: characterization and sensitivity to pollutants. Ecotoxicol Environ Saf 72:1481-1488

22. Bradford MM (1976) A rapid and sensitive method for the quantitation of microgram quantities of protein utilizing the principle of protein-dye binding. Anal Biochem 72(1-2):248-254

23. Buchman MF (2008) Screening Quick References Tables, NOAA OR\&R Report 08 - 1. Seattle WA, Office of Response and Restoration division, National oceanic and Atmospheric Administration

24. Carranza-Lopez L, Alvarez-Ortega N, Caballero-Gallardo K, Gonzalez-Montes A, Olivero-Verbel J (2020) Biomonitoring of Lead Exposure in Children from Two Fishing Communities at Northern Colombia. Biological Trace Element Research

25. Carvalho FP (2017) Pesticides, environment, and food safety. Food Energy Security 6:48-60

26. Ceratto N, Dondero F, Loo JW, Burlando B, Viarengo A (2002) Cloning and sequencing of a novel metallothionein gene in Mytilus galloprovincialis. Comp Biochem Physiol C: Toxicol Pharmacol 131(3):217-222

27. Chakraborty S, Ray M, Ray S (2012) Arsenic toxicity: A heart-breaking saga of a freshwater mollusc. Tissue Cell 44:151-155

28. Chan CY, Wang WX (2019) Biomarker responses in oysters Crassostrea hongkongensis in relation to metal contamination patterns in the Pearl River Estuary, southern China. Environ Pollut 251:264-276

29. Choi JY, Yu J, Yang DB, Ra K, Kim KT, Hong GH, Shin KH (2011) Acetylthiocholine (ATC) cleaving cholinesterase (ChE) activity as a potential biomarker of pesticide exposure in the Manila clam, Ruditapes philippinarum, of Korea. Marine Environmental Research 71:162-168

30. Cordy P, Veiga MM, Salih I, Al-Saadi S, Console S, Garcia O, Mesa LA, Velasquez-Lopez P, Roeser M (2011) Mercury contamination from artisanal gold mining in Antioquia, Colombia: The world's highest per capita mercury pollution. Science of the Total Environment $410-$ 41: $154-160$

31. Costa M, Zhuang Z, Huang X, Cosentino S, Klein CB, Salnikov K (1994) Molecular mechanisms of nickel carcinogenesis. Sci Total Environ 148:191-199

32. Cravo A, Pereira C, Gomes T, Cardoso C, Serafim A, Almeida C, Rocha T, Lopes B, Company R, Medeiros A, Norberto R, Pereira R, Araújo O, Bebianno MJ (2012) A multibiomarker approach in the clam Ruditapes decussatus to assess the impact of pollution in the Ria Formosa lagoon, South Coast of Portugal. Marine Environmental Research 75:23-34

33. D'Costa A, Shyama SK, Kumar P, Furtado S (2017) Genotoxic and Biochemical Biomarker Responses in Meretrix casta Exposed to Environmentally Relevant Concentrations of Cadmium. Journal of Biosensors Biomarkers Diagnostics 2(1):1-7

34. Damiens G, His E, Gnassia BM, Quiniou F, Romeo M (2004) Evaluation of biomarkers in oyster larvae in natural and polluted conditions. Comp Biochem Physiol C: Toxicol Pharmacol 138(2):121-128

35. David E, Tanguy A, Riso R, Quiniou L, Laroche J, Moraga D (2012) Responses of Pacific oyster Crassostrea gigas populations to abiotic stress in environmentally contrasted estuaries along the Atlantic coast of France. Aquat Toxicol 109:70-79

36. De Marchi L, Neto V, Pretti C, Figueira E, Chiellini F, Soares AM, Freitas R (2017) The impacts of emergent pollutants on Ruditapes philippinarum: biochemical responses to carbon nanoparticles exposure. Aquat Toxicol 187:38-47

37. Dondero F, Negri A, Boatti L, Marsano F, Mignone F, Viarengo A (2010) Transcriptomic and proteomic effects of a neonicotinoid insecticide mixture in the marine mussel (Mytilus galloprovincialis, Lam.). Sci Total Environ 408:3775-3786

38. Doran WJ, Cope WG, Rada RG, Sandheinrich MB (2001) Acetylcholinesterase inhibition in the threeridge mussel (Amblema plicata) by chlorpyrifos: Implications for biomonitoring. Ecotoxicol Environ Saf 49:91-98

39. Ellman GL, Courtney KD, Valentino Jr A, Featherstone RM (1961) A new and rapid colorimetric determination of acetylcholinesterase activity. Biochem Pharmacol 7:88-95

40. El-Shenawy NS, Moawad TIS, Mohallal ME, Abdel-Nabi IM, Taha IA (2009) Histopathologic biomarker response of clam, Ruditapes decussates, to organophosphorus pesticides Reldan and Roundup: A laboratory study. Ocean Science Journal 44:27-34

41. Eriksen KDH, Andersen T, Stenersen J (1990) Iso-metallothionein in cod induced by cadmium, zinc and nickel. In: Proceedings of the 12th Annual Conference on Physiological and Biochemical Approaches to the Toxicological Assessment of Environmental Pollution

42. Escartin E, Porte C (1997) The use of cholinesterase activities from Mytilus galloprovincialis in pollution monitoring. Environ Toxicol Chem 10:2090-2095

43. Fernandez A, Singh A, Jaffé R (2007) A literature review on trace metals and organic compounds of anthropogenic origin in the Wider Caribbean Region. Mar Pollut Bull 54:1681-1691

44. Fernandez-Maestre R, Johnson-Restrepo B, Olivero-Verbel J (2018) Heavy Metals in Sediments and Fish in the Caribbean Coast of Colombia: Assessing the Environmental Risk. International Journal of Environmental Research 12:289-301 
45. Franco AJ, León-Luna IM (2010) Geoquímica y concentraciones de metales pesados en un organismo de interés comercial (Corbula caribaea, D’Orbigny, 1842) en la zona submareal superficial de la Ciénaga de Mallorquín-Atlántico. Boletín Científico ClOH 28:69-83

46. Garcés-Ordóñez O, Vivas-Aguas LJ, Martínez M, Córdoba T, Contreras A, Obando P, Moreno Y, Muñoz J, Nieto Y, Ríos M, Sánchez J, Sánchez D (2016) Diagnóstico y Evaluación de la Calidad de las Aguas Marinas y Costeras del Caribe y Pacífico colombianos. Serie de Publicaciones Periódicas del Invemar No. 4 (2016). REDCAM. Informe Técnico 2015. INVEMAR, MADS y CAR costeras. Santa Marta

47. Geffard A, Amiard-Triquet C, Amiard JC, Mouneyrac C (2001) Temporal variations of metallothionein and metal concentrations in the digestive gland of oysters (Crassostrea gigas) from a clean and a metal-rich site. Biomarkers 6(2):91-107

48. Géret F, Jouan A, Turpin V, Bebianno MJ, Cosson. R.P (2002) Influence of metal exposure on metallothionein synthesis and lipid peroxidation in two bivalve mollusks: the oyster (Crassostrea gigas) and the mussel (Mytilus edulis). Aquat Living Resour 15:61-66

49. Gold-Bouchot G, Zapata O, Ceja V, Rodríguez G, Simá R, Aguirre ML, Vidal VM, Da Ros L, Nasci C (2007) Biological effects of environmental pollutants in American Oyster, Crassostrea virginica: A field study in Laguna de Términos, Mexico. International Journal of Environmental Health Research 1:171-184

50. Gold-Bouchot G, Zapata-Pérez O (2004) Contaminación, Ecotoxicología y Manejo Costero. Capítulo 18. Centro de Investigación y de Estudios Avanzados del IPN, Unidad Mérida. En: Rivera-Arriaga E., Villalobos-Zapata GJ., Azuz-Adeath I., Rosado-May F. (eds) (2004). El Manejo Costero en México. Universidad Autónoma de Campeche, SEMARNAT, CETYS-Universidad, Universidad de Quintana Roo

51. Gueguen Y, Denis S, Adrien S, Kevin M, Pierre G, Solène B, Marine N, Patrick B, Herehia H, Serge P, Gilles LM (2017) Response of the pearl oyster Pinctada margaritifera to cadmium and chromium: Identification of molecular biomarkers. Mar Pollut Bull 118:420-426

52. Hamer B, Jakšić Z, Pavičić-Hamer D, Perić L, Medaković D, Ivanković D, Pavičić J, Zilberberg C, Schröder HC, Müller WEG, Smodlaka N, Batel R (2008) Effect of hypoosmotic stress by low salinity acclimation of Mediterranean mussels Mytilus galloprovincialis on biological parameters used for pollution assessment. Aquat Toxicol 89:137-151

53. Hédouin L, Pringault O, Bustamante P, Fichez R, Warnau M (2011) Validation of two tropical marine bivalves as bioindicators of mining contamination in the New Caledonia lagoon: Field transplantation experiments. Water Res 45:483-496

54. Hernández- Moreno D, Soler F, Míguez MP, Pérez-López M (2010) Brain acetylcholinesterase, malondialdehyde and reduced glutathione as biomarkers of continuous exposure of tench, Tinca tinca, to carbofuran or deltamethrin. Sci Total Environ 408:4976-4983

55. INVEMAR (2017) Diagnóstico y evaluación de la calidad de las aguas marinas y costeras en el Caribe y Pacífico colombianos. Garcés, O. y L. Espinosa (Eds.). REDCAM: INVEMAR, MADS y CAR costeras. Informe Técnico 2016. Serie de Publicaciones Periódicas No. 4 (2017) del INVEMAR. Santa Marta

56. Ivanina AV, Taylor C, Sokolova IM (2009) Effects of elevated temperature and cadmium exposure on stress protein response in eastern oysters Crassostrea virginica (Gmelin). Aquat Toxicol 91:245-254

57. Ivanković D, Pavičić J, Erk M, Filipović-Marijić V, Raspor B (2005) Evaluation of the Mytilus galloprovincialis Lam. digestive gland metallothionein as a biomarker in a long-term field study: Seasonal and spatial variability. Mar Pollut Bull 50:1303-1313

58. Jenny MJ, Ringwood AH, Schey K, Warr GW, Chapman RW (2004) Diversity of metallothioneins in the American oyster, Crassostrea virginica, revealed by transcriptomic and proteomic approaches. Eur J Biochem 271(9):1702-1712

59. Kimbrough KL, Johnson WE, Lauenstein GG, Christensen JD, Apeti DA (2008) An assessment of two decades of contaminant monitoring in the nation's coastal zone. NOAA Technical Memorandum NOS NCCOS, p 74

60. Leiniö S, Lehtonen KK (2005) Seasonal variability in biomarkers in the bivalves Mytilus edulis and Macoma balthica from the northern Baltic Sea. Comparative Biochemistry and Physiology Part C: Toxicology \& Pharmacology 140, 408-421

61. Lewis M, Mayer F, Powell R, Nelson M, Klaine S, Henry M, Dickson G (1995) Ecotoxicology and risk assessment for wetlands. Society of Environmental Toxicology and Chemistry (SETAC). SETAC Pellston Workshop on Ecotoxicology and Risk Assessment for Wetlands. 30 July- 3 August 1995. Fairmont Hot Springs, Anaconda. Montana

62. Liu X, Wang WX (2016) Time changes in biomarker responses in two species of oyster transplanted into a metal contaminated estuary. Sci Total Environ 544:281-290

63. Lüchmann KH, Mattos JJ, Siebert MN, Granucci N, Dorrington TS, Bícego MC, Taniguchi S, Sasaki ST, Daura-Jorge FG, Bainy ACD (2011) Biochemical biomarkers and hydrocarbons concentrations in the mangrove oyster Crassostrea brasiliana following exposure to diesel fuel water-accommodated fraction. Aquat Toxicol 105:652-660

64. Luo L, Ke C, Guo X, Shi B, Huang M (2014) Metal accumulation and differentially expressed proteins in gill of oyster (Crassostrea hongkongensis) exposed to long-term heavy metal-contaminated estuary. Fish Shellfish Immunology 38:318-329

65. MacDonald DD, Carr RS, Calder FD, Long ER, Ingersoll CG (1996) Development and evaluation of sediment quality guidelines for Florida coastal waters. Ecotoxicology 5:253-278 
66. Mackay EA, Overnell J, Dunbar B, Davidson I, Hunziker PE, Kägi JHR, Fothergill JE (1993) Complete amino acid sequences of five dimeric and four monomeric forms of metallothionein from the edible mussel Mytilus edulis. Eur J Biochem 218:183-194

67. Magni P, De Falco G, Falugi C, Franzoni M, Monteverde M, Perrone E, Sgro M, Bolognesi C (2006) Genotoxicity biomarkers and acetylcholinesterase activity in natural populations of Mytilus galloprovincialis among a pollution gradient in the Gulf of Oristano (Sardinia, western Mediterranean). Environ Pollut 142:65-72

68. Moncaleano- Niño AM, Luna- Acosta A, Gómez-Cubillos MC, Villamil L, Ahrens MJ (2018) Cholinesterase activity in the cup oyster Saccostrea sp. exposed to chlorpyrifos, imidacloprid and cadmium. Ecotoxicol Environ Saf 151:242-254

69. Moncaleano-Niño AM, Barrios-Latorre SA, Poloche-Hernández JF, Becquet V, Huet V, Villamil L, Thomas-Guyon H, Ahrens MJ, Luna-Acosta A (2017) Alterations of tissue metallothionein and vitellogenin concentrations in tropical cup oysters (Saccostrea sp.) following shortterm (96 h) exposure to cadmium. Aquat Toxicol 185:160-170

70. Monserrat JM, Bianchini A, Bainy AC (2002) Kinetic and toxicological characteristics of acetylcholinesterase from the gills of oysters (Crassostrea rhizophorae) and other aquatic species. Marine Environmental Research 54:781-785

71. Monserrat JM, Martínez PE, Geracitano LA, Amado LL, Martins CMG, Pinho GLL, Chaves IS, Ferreira-Cravo M, Ventura-Lima J, Bianchini A (2007) Pollution biomarkers in estuarine animals: Critical review and new perspectives. Comparative Biochemistry and Physiology Part C: Toxicology \& Pharmacology 146, 221-234

72. Montaudouin X, Paul-Pont I, Lambert C, Gonzalez P, Raymond N, Jude F, Legeay A, Baudrimont M, Dang M, Le Grand F, Le Goïc N, Bourasseau I, Paillard C (2010) Bivalve population health: Multistress to identify hot spots. Mar Pollut Bull 60:1307-1318

73. Mora P, Fournier D, Narbonne JF (1999) Cholinesterases from the marine mussels Mytilus galloprovincialis Lmk. and M. edulis L. and from the freshwater bivalve Corbicula fluminea Muller. Comp Biochem Physiol C 122(3), 353-361

74. Morillo J, Usero J, Gracia I (2004) Heavy metal distribution in marine sediments from the southwest coast of Spain. Chemosphere $55: 431-442$

75. Mouneyrac C, Amiard JC, Amiard-Triquet C (1998) Effects of natural factors (salinity and body weight) on cadmium, copper, zinc and metallothionein-like protein levels in resident populations of oysters Crassostrea gigas from a polluted estuary. Mar Ecol Prog Ser 162:125-135

76. Mourgaud Y, Martinez É, Geffard A, Andral B, Stanisiere JY, Amiard JC (2002) Metallothionein concentration in the mussel Mytilus galloprovincialis as a biomarker of response to metal contamination: validation in the field. Biomarkers 7(6):479-490

77. Olivero-Verbel J, Johnson- Restrepo B, Baldiris-Avila R, Güette-Fernández J, Magallanes-Carreazo E, Vanegas-Ramírez L, Kunihiko N (2008) Human and crab exposure to mercury in the Caribbean coastal shoreline of Colombia: impact from an abandoned chlor-alkali plant. Environ Int 34:476-482

78. Peric L, Fafanđel M, Glad M, Bihari N (2012) Heavy metals concentration and Metallothionein content in resident and caged Mussels Mytilus galloprovincialis from Rijeka Bay, Croatia. Fresenius Environ Bull 21(9):2785-2794

79. Peric L, Ribaric L, Nerlovic V (2013) Cholinesterase activity in the tissues of bivalves Noah's ark shell (Arca noae) and warty venus (Venus verrucosa): Characterization and in vitro sensitivity to organophosphorus pesticide trichlorfon. Comparative Biochemistry Physiology $\mathrm{B}$ 165:243-249

80. Prato E, Biandolino F, Scardicchio C (2006) Test for Acute Toxicity of Copper, Cadmium, and Mercury in Five Marine Species. Turkish Journal of Zoology 30:285-290

81. Rajkumar J (2013) Reduced glutathione and acetylcholinesterase expressions in Perna indica exposed to trivalent arsenic. International Journal of Biological Research 1:1-4

82. Ramakritinan CM, Chandurvelan R, Kumaraguru AK (2012) Acute Toxicity of metals: Cu, Pb, Cd, Hg, and Zn on marine molluscs, Cerithidea cingulata G., and Modiolus philippinarum H. Indian Journal of Geo-Marine Sciences 41(2):141-145

83. Ramdine G, Fichet D, Louis M, Lemoine S (2012) Polycyclic aromatic hydrocarbons (PAHs) in surface sediment and oysters (Crassostrea rhizophorae) from mangrove of Guadeloupe: Levels, bioavailability and effects. Ecotoxicol Environ Saf 79:80-89

84. Rasmussen LP, Hage E, Karlog O (1983) Histopathological studies of the acute and chronic toxic effects of 2 N-nitroso-compounds on the blue mussel (Mytilus edulis). Nordisk Veterinarian Medicine 35:306-313

85. Raspor B, Dragun Z, Erk M, Ivankovic D, Pavicic J (2004) Is the digestive gland of Mytilus galloprovincialis a tissue of choice for estimating cadmium exposure by means of metallothioneins? Sci Total Environ 333:99-108

86. Roesijadi G, Hansen KM, Unger ME (1997) Concentration-Response relationships for Cd, Cu, and Zn and metallothionein mRNA induction in larvae of Crassostrea virginica. Comparative biochemistry and physiology part C: Pharmacology, Toxicology and Endocrinology 118 , 267-270 
87. Sandahl JF, Jenkins JJ (2002) Pacific steelhead (Oncorhynchus mykiss) exposed to chlorpyrifos: benchmark concentration estimates for acetylcholinesterase inhibition. Environ Toxicol Chem 21(11):2452-2458

88. Santos HM, Diniz MS, Costa PM, Peres I, Costa MH, Alves S, Capelo JL (2007) Toxicological effects and bioaccumulation in the freshwater clam (Corbicula fluminea) following exposure to trivalent arsenic. Environ Toxicol 22:502-509

89. Senger MR, Rosemberg DB, Rico EP, de Bem Arizi M, Dias RD, Bogo MR, Bonan CD (2006) In vitro effect of zinc and cadmium on acetylcholinesterase and ectonucleotidase activities in zebrafish (Danio rerio) brain. Toxicol In Vitro 20:954-958

90. Serafim A, Company R, Lopes B, Fonseca VF, Franca S, Vasconcelos P, Bebianno MJ, Cabral HN (2012) Application of an integrated biomarker response index (IBR) to assess temporal variation of environmental quality in two Portuguese aquatic systems. Ecol Ind 19:215-225

91. Singh A, Laurence M (2008) Examination of policies and MEAs commitment by SIDS for sustainable management of the Caribbean Sea. Marine Policy 32:274-282

92. Sokal RR, Rohlf FJ (1995) Biometry: the principles of statistics in biological research. WH Freeman and Co., New York

93. Spalding M, Kramer P (2004) The Caribbean. Defying Ocean's End: An Agenda for Action. Island Press, Washington DC, pp 7-41

94. Sun M, Liu G, Lin H, Zhang T, Guo W (2018) Effect of salinity on the bioaccumulation and depuration of Cadmium in the pacific cupped oyster, Crassostrea gigas. Environmental Toxicology and Pharmacology, In press

95. Tejeda- Benitez L, Flegal R, Odigie K, Olivero- Verbel J (2016) Pollution by metals and toxicity assessment using Caenorhabditis elegans in sediments from the Magdalena River, Colombia. Environmental Pollution 212, 238-250

96. Thevenod F, Lee WK (2013) Cadmium and cellular signaling cascades: interactions between cell death and survival pathways. Archives of Ecotoxicology 87:1743-1786

97. Thomann RV, Mahony JD, Mueller R (1995) Steady-state model of biota sediment accumulation factor for metals in 2 marine bivalves. Environ Toxicol Chem 14:1989-1998

98. Tsangaris C, Kormas K, Strogyloudi E, Hatzianestis I, Neofitou C, Andral B, Galgani F (2010) Multiple biomarkers of pollution effects in caged mussels on the Greek coastline. Comp Biochem Physiol C: Toxicol Pharmacol 151(3):369-378

99. UNEP (2008) Regionally Based Assessment of persistent Toxic Substances. UNEP- United Nations- GEF, 211 pp

100. Unger ME, Chen TT, Murphy CM, Vestling MM, Fenselau Roesijadi G (1991) Primary structure of molluscan metallothioneins deduced from PCR-amplified cDNA and mass spectrometry of purified proteins. Biochem Biophys Acta 1074:371-377

101. Valbonesi P, Sartor G, Fabbri E, E (2013) Characterization of cholinesterase activity in three bivalves inhabiting the North Adriatic Sea and their possible use as sentinel organisms for biosurveillance programmes. Sci Total Environ 312:79-88

102. Vallejo Toro PP, Vásquez Bedoya LF, Correa ID, Franco B, Alcantara- Carrió GR, Baena JPalacio, JA (2016) Impact of terrestrial mining and intensive agriculture in pollution of estuarine surface sediments: Spatial distribution of trace metals in the Gulf of Urabá, Colombia. Mar Pollut Bull 111(1-2):311-320

103. Viarengo A (1989) Heavy metals in marine invertebrates: mechanisms of regulation and toxicity at the cellular level. Review of Aquatic Sciences 1:295-317

104. Viarengo A, Ponzano E, Dondero F, Fabbri R (1997) A simple spectrophotometric method for metallothionein evaluation in marine organisms: an application to Mediterranean and Antarctic molluscs. Marine Environmental Research 44:69-84

105. Vivas-Aguas LJ, Espinosa L, Sánchez J, Cadavid B, Bautista P, Quintero M, Betancourt J, Parra JP, Parra LG, Cuadrado I, Ibarra K (2012) Diagnóstico y evaluación de la calidad ambiental marina en el Caribe y Pacífico Colombiano. REDCAM. Informe Técnico 2012. INVEMAR. Santa Marta

106. Vivas-Aguas LJ, Ibarra K, Sánchez J, Martínez M, Nieto Y, Moreno Y, Cuadrado I, Obando P, Garces O, Sánchez, D., Villaraga, M., Sierra 0 (2015) Diagnóstico y evaluación de la calidad de las aguas marinas y costeras del Caribe y Pacífico Colombiano. Serie de publicaciones periódicas del INVEMAR No 4 (2015). REDCAM. Informe Técnico 2014. INVEMAR. Santa Marta

107. Wang WX, Rainbow PS (2010) Significance of metallothioneins in metal accumulation kinetics in marine animals. Comparative Biochemistry Physiology Part C: Toxicology pharmacology 152(1):1-8

108. Weng N, Wang WX (2014) Improved tolerance of metals in contaminated oyster larvae. Aquatic Toxicology 146:61-69

109. Yingprasertchai T, Yu R, Tran T, Chong Kong R, O'Connor W, MacFarlane G (2019) Characterization of the metallothionein gene in the Sydney rock oyster and its expression upon metal exposure in oysters with different prior metal exposure histories. Marine Environmental Research 151:104775

110. Zar JH (2010) Biostatistical analysis, 5th edn. Prentice Hall, New Jersey

\section{Supplemental Data}

Page 26/32 
Supplemental files are not available with this version.

\section{Figures}

Figures 1-9, and 26 are not available in this version

\section{Tables}

Tables 1-6 are not available in this version.

\section{Figures}

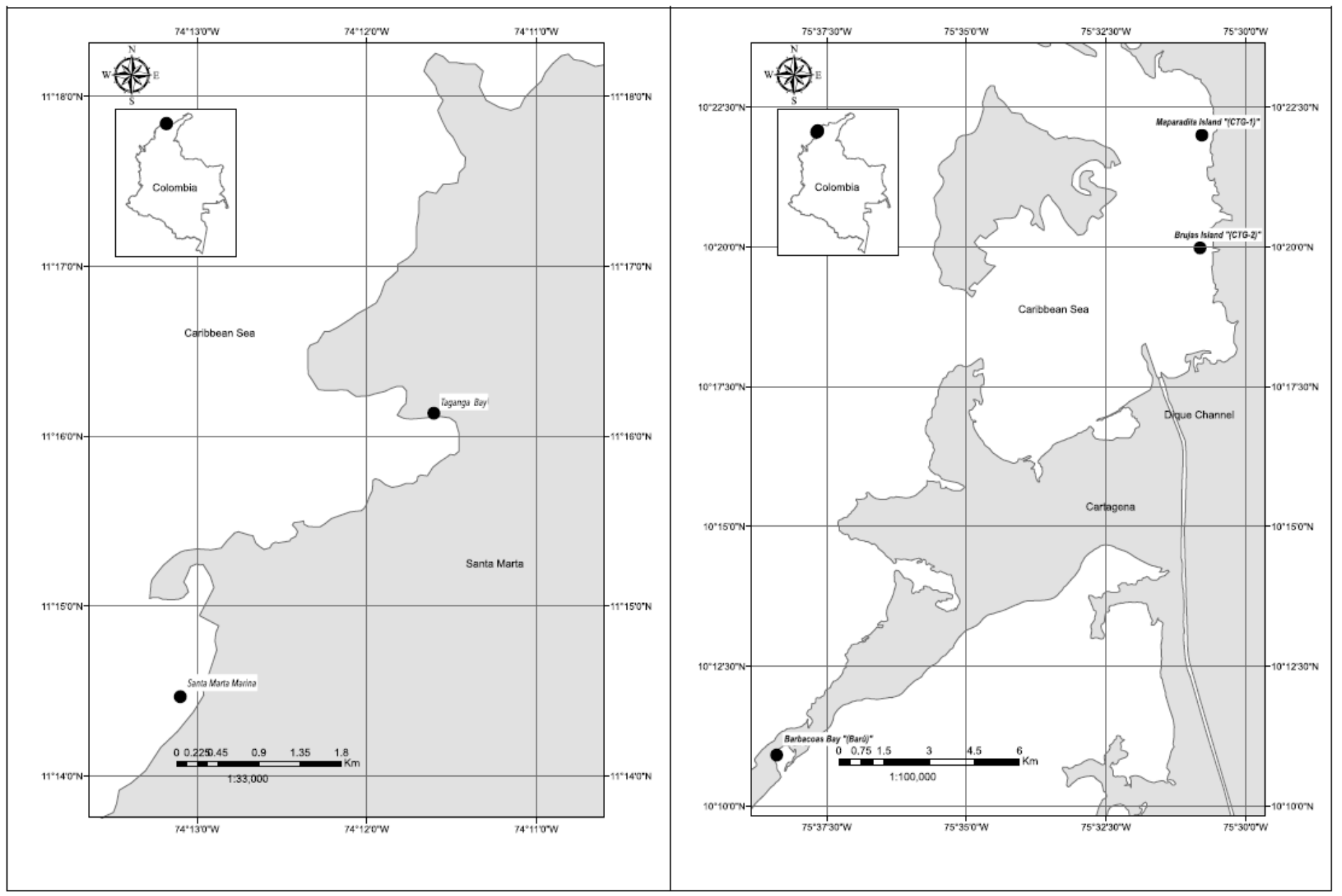

Figure 1

Study Area, with the 5 sampling stations indicated. (Figure 10 in the manuscript.) 


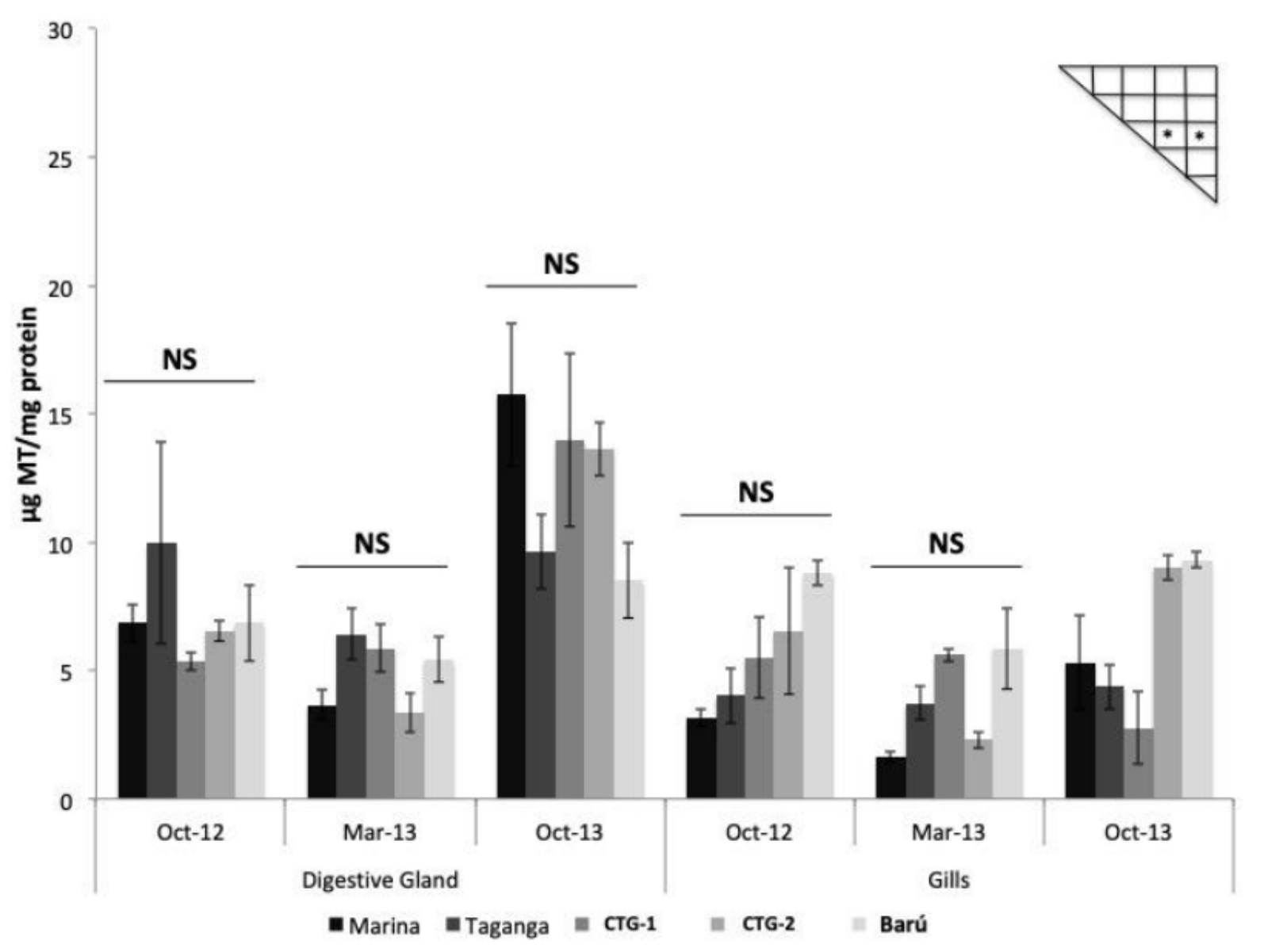

Figure 2

Metallothionein-like protein (MT) concentration ( $\mu \mathrm{g} \mathrm{MT} / \mathrm{mg}$ protein, mean $\pm 1 \mathrm{SE}$ ) in digestive gland and gills of cup oysters, for five different sampling stations (Taganga, Santa Marta Marina, Barú, Ctg-1 and Ctg-2) on three sampling dates (October 2012, March 2013, and October 2013). Triangle matrix above: asterisk ${ }^{*}$ ) indicates statistical difference at $p<0.05$; NS: no significant difference between stations (Tukey pairwise comparisons, for fixed date, $p>0.05$ ). (Figure 11 in the manuscript.) 


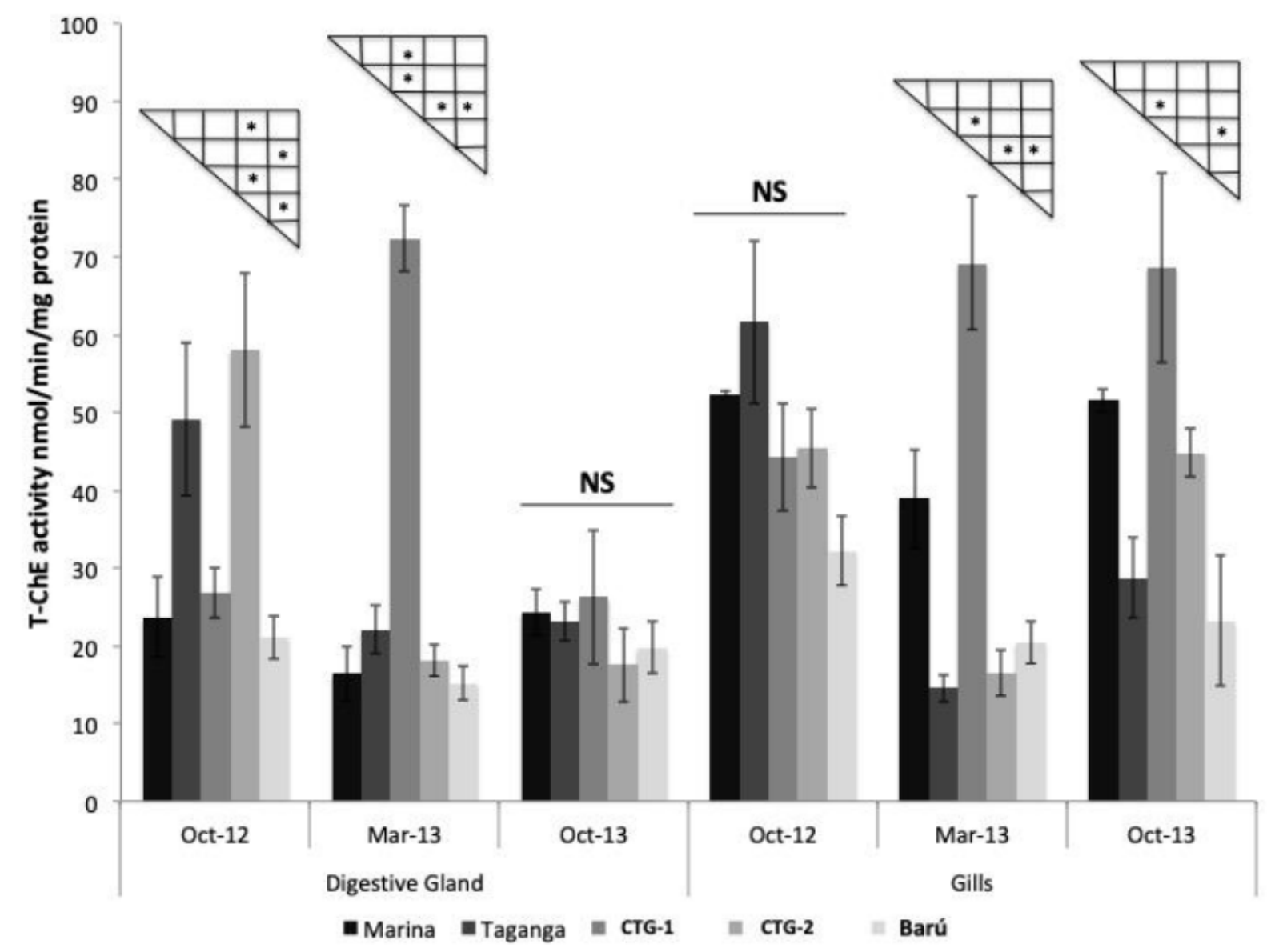

Figure 3

Total cholinesterase (T-ChE) activity (mean $\pm 1 \mathrm{SE}$ ) in digestive gland and gills of cup oysters, for five different sampling stations (Taganga, Santa Marta Marina, Barú, Ctg-1 and Ctg-2) on three sampling dates (October 2012, March 2013, and October 2013). Triangle matrix above: asterisk (*) indicates statistical difference at $\mathrm{p}<0.05$; NS: no significant difference between stations (Tukey pairwise comparisons, for fixed date, $p>0.05$ ). (Figure 12 in the manuscript.) 


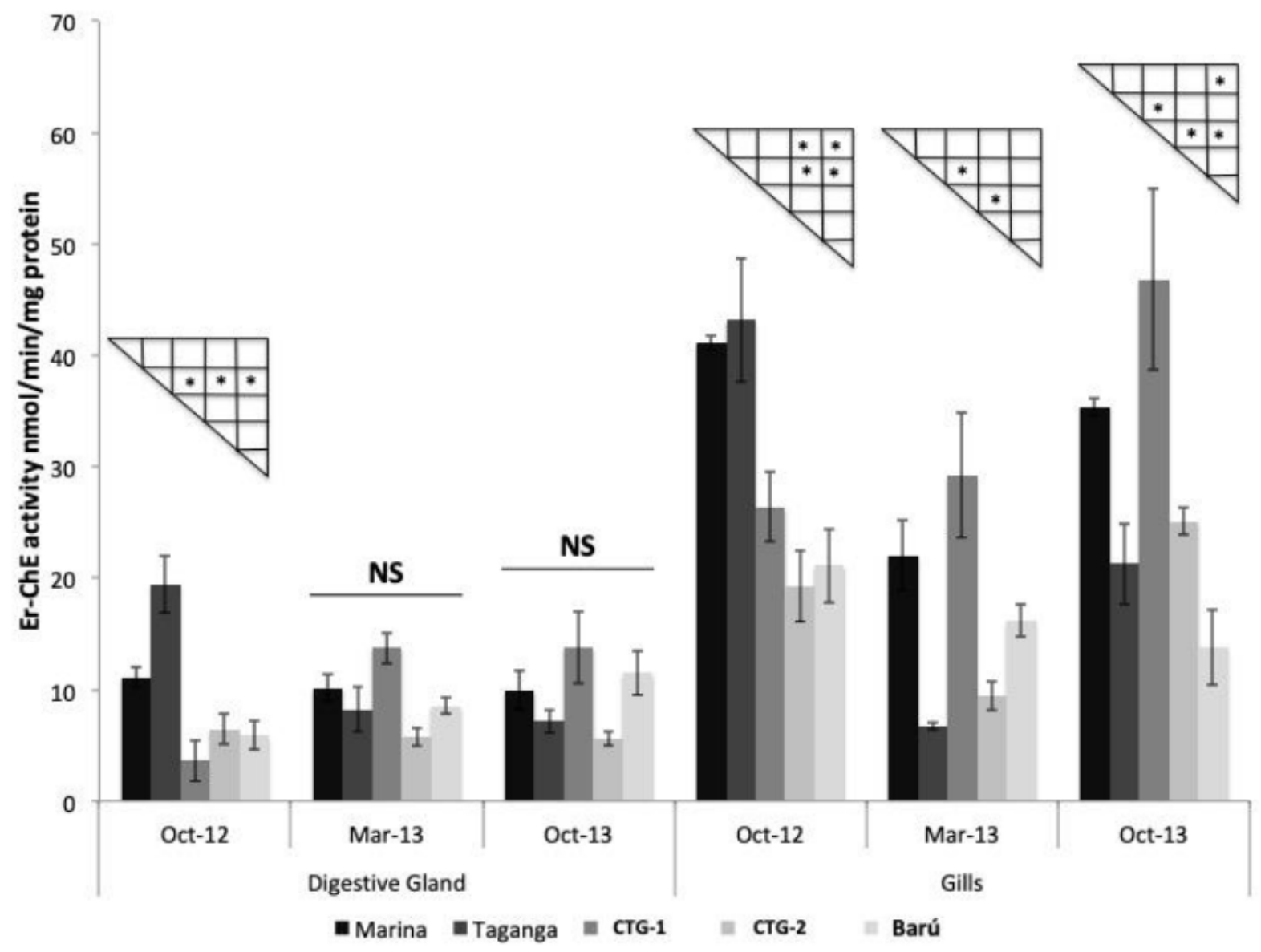

Figure 4

Eserine-resistant cholinesterase (Er-ChE) activity (mean $\pm 1 \mathrm{SE}$ ) in digestive gland and gills of cup oysters, for five different sampling stations (Taganga, Santa Marta Marina, Barú, Ctg-1 and Ctg-2) on three sampling dates (October 2012, March 2013, and October 2013). Triangle matrix above: asterisk $\left({ }^{*}\right)$ indicates statistical difference at $p<0.05$; NS: no significant difference between stations (Tukey pairwise comparisons, for fixed date, $p>0.05$ ). (Figure 13 in the manuscript.) 


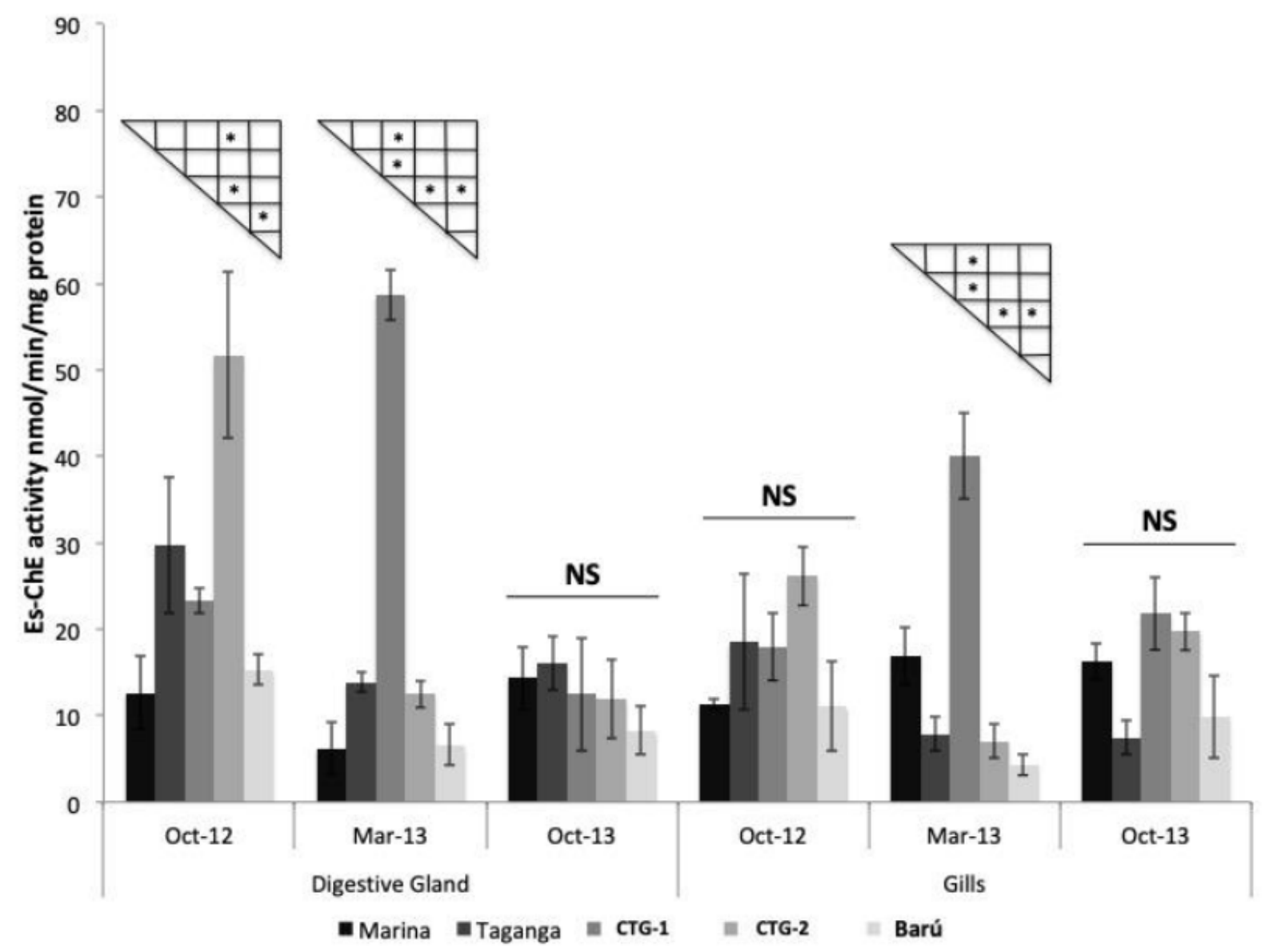

\section{Figure 5}

Eserine-sensitive cholinesterase (Es-ChE) activity (mean $\pm 1 \mathrm{SE}$ ) in digestive gland and gills of cup oysters, for five different sampling stations (Taganga, Santa Marta Marina, Barú, Ctg-1 and Ctg-2) on three different sampling dates (October 2012, March 2013, and October 2013). Triangle matrix above: asterisk $\left(^{\star}\right)$ indicates statistical difference at $p<0.05$; NS: no significant difference between stations (Tukey pairwise comparisons, for fixed date, $p>0.05)$. (Figure 14 in the manuscript.)
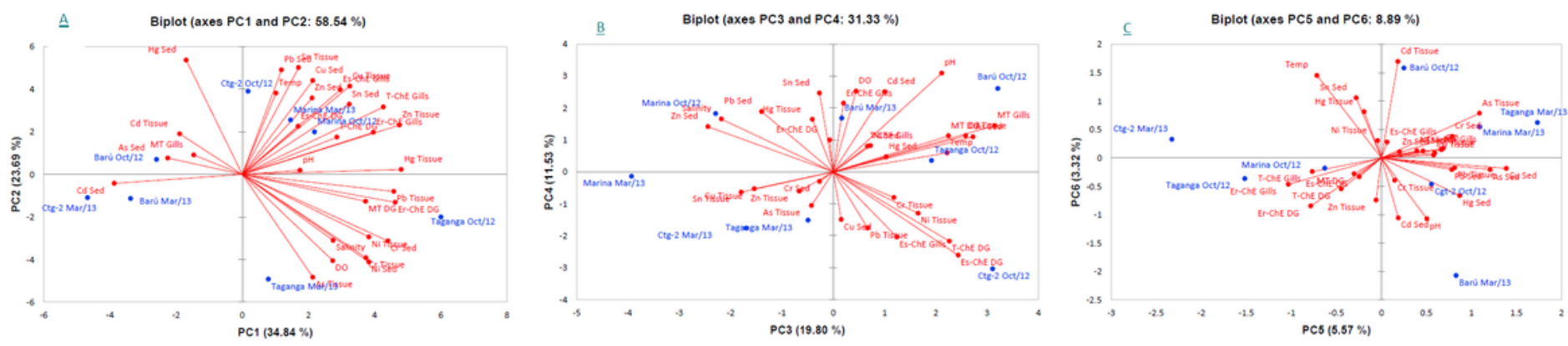

Figure 6

PCA (Components 1 to 6 ) of water physical-chemical parameters (salinity, temp, pH, DO), tissue metal and sediment metal concentrations ( $\mathrm{Sn}, \mathrm{Hg}, \mathrm{Pb}, \mathrm{Cr}, \mathrm{Cu}, \mathrm{Zn}, \mathrm{As}, \mathrm{Cd}$ and Ni) and biomarkers (MT, T-ChE, Er-ChE and Es-ChE) for four sampling stations (Taganga, Santa Marta Marina, Barú, and Ctg-2, excluding Ctg-1) in October 2012 and March 2013. Units on axes indicate respective factor scores. Variance contribution (\%) indicated for each principal component axis (A-PC1 and PC2, B-PC3 and PC4, C-PC5 and PC6). Lines indicate eigenvectors of individual variables; square symbols mark factor scores of individual sampling stations. (Figure 15 in the manuscript.) 
Biplot (axes FQ1 and FQ2: $88.55 \%$ )

$\underline{A}$

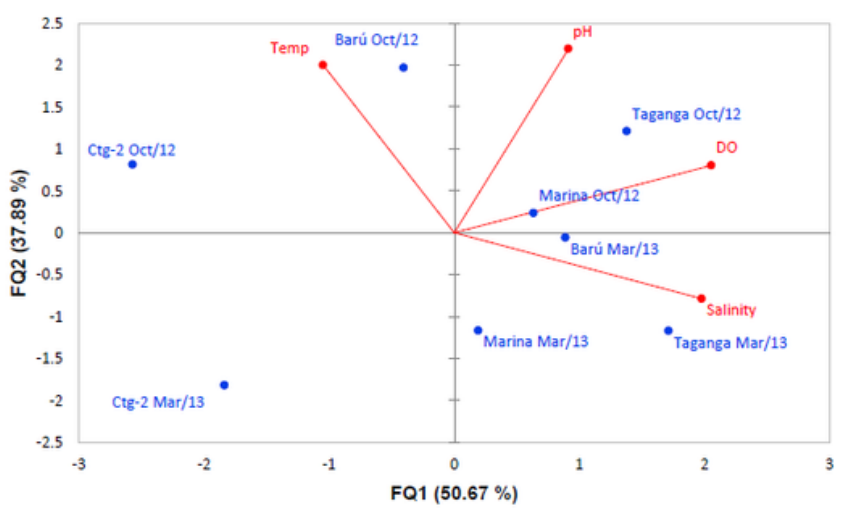

Biplot (axes FQ3 and FQ4: $11.45 \%$ )

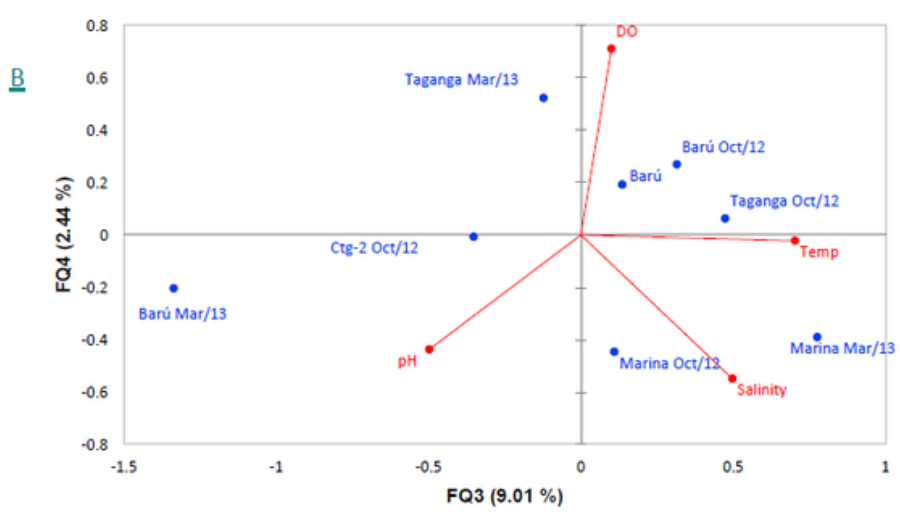

\section{Figure 7}

PCA (Components FQ1 to FQ4) of water physical-chemical parameters (salinity, temperature, pH, DO), for the four sampling stations (Taganga, Santa Marta Marina, Barú, and Ctg-2, excluding Ctg-1) in October 2012 and March 2013. (Figure 16 in the manuscript.)
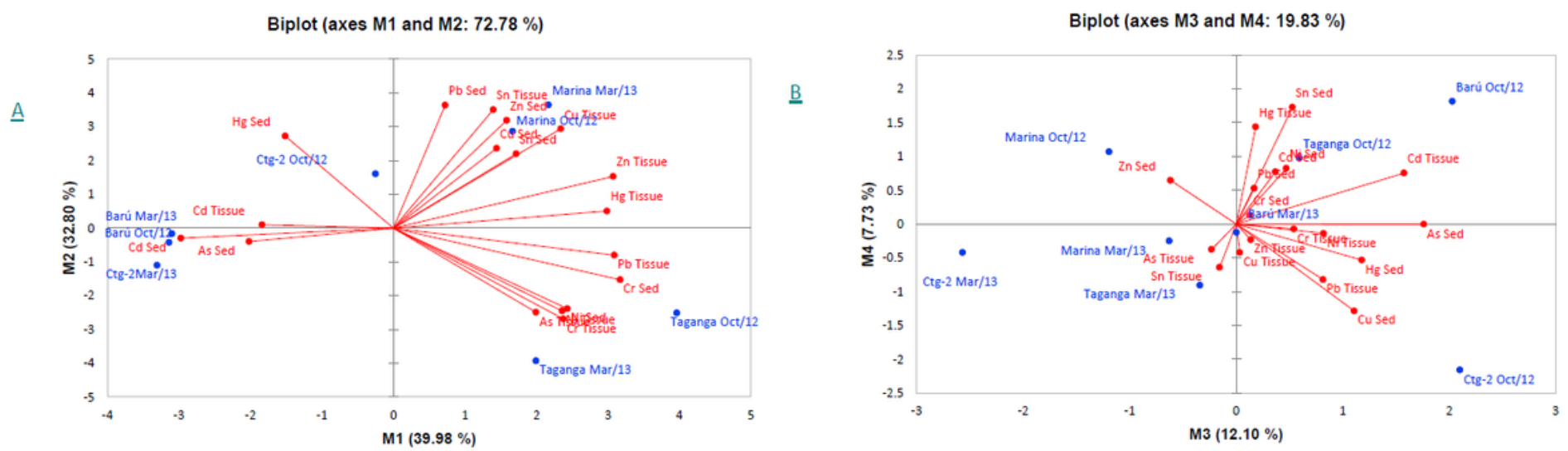

\section{Figure 8}

PCA (Components M1 to M4) of tissue and sediment metal concentrations (Sn, Hg, Pb, Cr, Cu, Zn, As, Cd and Ni) for the four sampling stations (Taganga, Santa Marta Marina, Barú and Ctg-2, excluding Ctg-1) in October 2012 and March 2013. (Figure 17 in the manuscript.) 